\title{
EL COMPONENTE ECONÓMICO ESCOLAR COMO INSTRUMENTO CONFIGURADOR DE IDENTIDADES. DE LA NACIÓN PRODUCTIVA A LA NACIÓN DEMOCRÁTICA (ESPAÑA, 1960-1985) ${ }^{\alpha}$
}

\author{
The school economic component as an identity configuring \\ instrument. From the productive Nation to the democratic \\ Nation (Spain, 1960-1985)
}

\section{Yovana Hernández Laina ${ }^{\beta}$}

Fecha de recepción: 30/11/2019 • Fecha de aceptación: 11/03/2020

Resumen. El objetivo de esta investigación es mostrar cómo en España se manifestaron y configuraron las identidades individuales y colectivas a través del discurso económico difundido por los manuales escolares del franquismo desarrollista y la Transición hacia la democracia. Se parte del concepto de identidad entendido como una representación mental compartida, que se viene configurando desde la infancia, así como de la premisa de que tanto las identidades individuales como las colectivas contienen un componente económico. Estas identidades se configuran mediante una socialización que se lleva a cabo a través de procesos de identificación con tipologías de discursos económicos, que van cambiando y adaptándose a los procesos político-económicos y sociales. La muestra de manuales escolares analizados está constituida por treinta ejemplares relacionados con las Ciencias Sociales, de las décadas de los años sesenta, setenta y comienzos de los ochenta del siglo XX. La metodología de estudio es el análisis crítico del discurso (tanto de textos como de imágenes), que se ha

\footnotetext{
a Este trabajo se ha desarrollado en el marco del Proyecto de Investigación «Economía, patriotismo y ciudadanía: La dimensión económica de la socialización política en los manuales escolares españoles desde el tardofranquismo hasta la Transición». Ministerio de Economía y Competitividad. Referencia: EDU2016-78143-R.

${ }^{\text {B }}$ Centro de Investigación MANES, Universidad Nacional de Educación a Distancia. C/ Juan del Rosal, 14, 28040 Madrid, España. yovanahl@hotmail.com / yhernandez@edu.uned.es (D) https://orcid.org/0000-0002-3034-3907
}

Cómo citar este artículo: Hernández Laina, Yovana. «El componente económico escolar como instrumento configurador de identidades. De la nación productiva a la nación democrática (España, 1960-1985)». Historia y Memoria de la Educación 12 (2020): 167-208 
llevado a cabo a través de una serie de indicadores, usando además el estudio de los contextos para la triangulación de datos. La investigación permite comprobar cómo el componente económico del discurso de los manuales tiene la capacidad de configurar identidades, a través de mecanismos de identificación y pertenencia, condicionados por las estructuras de poder.

Palabras clave: Manuales escolares; Identidades; Desarrollismo franquista; Transición política; Componente económico.

Abstract. The aim of this study is to show how individual and collective identities were manifested and shaped in Spain through the economic discourse disseminated by the school textbooks during the period of accelerated economic growth (developmentalism) under Franco and during the transition towards democracy. It begins with the concept of identity, understood as a shared mental representation which is shaped starting in childhood, as well as with the premise that both individual and collective identities contain an economic component. These identities are configured by means of a socialization that is carried out through processes of identification with typologies of economic discourses, which change and adapt to political-economic and social contexts. The sample of school textbooks analysed is made up of thirty units pertaining to the Social Sciences, from the sixties, seventies and early eighties of the 20th century. The methodological approach used is the critical analysis of discourse (both texts and images), which has been carried out through a series of indicators, also using the study of contexts for data triangulation. The research allows us to verify how the economic component of the discourse conveyed by the textbooks has the capacity to configure identities, through mechanisms of identification and belonging, that are conditioned by the power structures.

Keywords: Textbooks; Identities; Francoist developmentalism; Political transition; Economic component.

\section{INTRODUCCIÓN}

Este trabajo, que resume los resultados de una investigación más amplia sobre el tema, ${ }^{1}$ surge del vacío detectado en torno a un análisis riguroso de las potencialidades de la transmisión del contenido económico escolar, y de cómo este tiene la capacidad de influir en los procesos

\footnotetext{
1 La fundamentación de este trabajo se encuentra en la Tesis Doctoral de la autora: Yovana Hernández Laina, «Cultura económica y socialización política en los manuales escolares del tardofranquismo y la Transición española (1960-1985)» (Tesis doctoral, UNED, 2018).
} 
de configuración de identidades. Por tales motivos, hemos tratado de analizar el componente económico escolar que subyace en los discursos de los manuales y el currículum del franquismo desarrollista ${ }^{2}$ y la Transición ${ }^{3}$ española, como instrumento capaz de configurar nuevas identidades sociales, individuales y colectivas, asociadas a las raíces del pensamiento político-económico. En concreto, el periodo histórico que contempla este trabajo parte del año 1960 y llega hasta el año 1985. Los motivos de la elección de este periodo se basan precisamente en la importancia de los cambios políticos, económicos y sociales que se producen durante estos años. A su vez, se han establecido subperiodos coincidiendo con las décadas. La primera década contemplada es la de los años sesenta, en la cual se dan grandes cambios en política económica, que parten del Plan de Estabilización de 1959 y los sucesivos Planes de Desarrollo. El diseño de estas medidas económicas, provenientes de las teorías internacionales del desarrollo y la implantación del desarrollismo tecnócrata, producen el despegue económico conocido como «milagro económico español». Por otro lado, la década de los setenta supone el fin de la dictadura y el proceso de transición hacia una joven democracia. Por tanto, consideramos esta etapa como parte decisiva en la historia económica y social de la España del siglo XX. Finalmente, en la primera mitad de la década de los ochenta se constituye el proceso de consolidación democrática, sobre todo a partir del año 1982 cuando por primera vez gana las elecciones el Partido Socialista Obrero Español (PSOE), y en 1985 se aprueba el ingreso de España en la Comunidad Económica Europea.

En cuanto al enfoque teórico de este trabajo, partimos de la consideración de que tanto las identidades individuales como las colectivas abarcan un componente económico, ${ }^{4}$ ya que se configuran en base a una

\footnotetext{
${ }^{2}$ La fase final de la dictadura franquista (1959-1975) es conocida como segundo franquismo o franquismo desarrollista, durante el cual se produjeron grandes cambios económicos y sociales.

${ }^{3}$ Existe un amplio debate sobre la delimitación temporal del periodo de la Transición a la democracia tras la dictadura franquista. El propio colectivo de historiadores no ha consensuado aún un criterio unificador sobre este asunto. Para nuestro estudio hemos delimitado este periodo desde 1975, fecha de la muerte del dictador, hasta 1985, fecha de entrada de España en la Comunidad Económica Europea.

${ }^{4}$ Kira Mahamud y Yovana Hernández, «Teaching Economics with Spanish Primary School Textbooks during the Franco Dictatorship and the Transition to Democracy (1962-1982)», Journal of Educational Media, Memory, and Society 9, no. 1 (2017): 72.
} 
socialización que se lleva a cabo a través de procesos de identificación nacional, internacional, regional y local basados en estatus económicos. De acuerdo con Bruce Longenecker y Kelly Liebengood, la dimensión económica,

shapes and controls the identities of things-that-matter, from whole nations at one end of the spectrum to distinct and diverse individuals at the other end. Quite simply, the current crisis has underscored what many knew already - that economic status is a primary factor in the taxonomy of personal and corporate identity the world over.$-^{5}$

Las escuelas de las sociedades modernas se han materializado como agentes de reproducción social, ${ }^{6}$ y los manuales escolares han sido un seductor instrumento de socialización política para los Estados. ${ }^{7} \mathrm{La}$ educación estatal institucional se ha mostrado históricamente como un arma poderosa para los mecanismos del poder, utilizándose como instrumento de unificación y adquisición de conciencia e identidad nacional. ${ }^{8}$ Partimos del concepto de identidad ${ }^{9}$ como una representación mental compartida por un grupo, que no es innata, sino que se va configurando desde la infancia a través de discursos y prácticas sociales ${ }^{10}$ y va transformándose conforme se construye. Uno de los mecanismos

\footnotetext{
${ }^{5}$ Bruce Longenecker y Kelly Liebengood, Engaging Economics: New Testament Scenarios and Early Christian Reception (Michigan: William Eerdmans Publishing Company, 2009), 4.

${ }^{6}$ Pierre Bourdieu, Las estrategias de la reproducción social (México: Siglo Veintiuno, 2011).

7 Carolyn P. Boyd, «De la memoria oficial a la memoria histórica: La Guerra Civil y la dictadura en los textos escolares de 1939 al presente», en Memoria de la guerra y del franquismo, ed. Santos Juliá (Madrid: Taurus Ediciones, 2006), 80.

8 Jacques Bousquet, Economía política de la educación (Madrid: Instituto de Estudios Políticos, 1960), 50 .

9 Sobre el concepto de identidad consultar: Peter L. Berger y Thomas Luckmann, La construcción social de la realidad (Buenos Aires: Amorrortu, 1988); Max Weber, Economía y Sociedad (México: Fondo de Cultura Económica, 1979); Joan-Josep Pujadas Muñoz, Etnicidad. Identidad cultural de los pueblos (Madrid: Eudema, 1993); Anthony Giddens, Modernidad e identidad del yo (Barcelona, Península, 1995); Leticia Méndez, Identidad: análisis y teoría, simbolismo, sociedades complejas, nacionalismo y etnicidad (México: UNAM, 1996); Manuel Castells, La era de la información. Economía, sociedad y cultura (Madrid: Alianza, 1998); Carolyn P. Boyd, Historia Patria. Política, historia e identidad nacional en España. 1875-1975 (Barcelona: Ediciones Pomares Corredor, 2000).

${ }^{10}$ Encarna Atienza Cerezo y Teun A. Van Dijk, «Identidad social e ideología en libros de texto españoles de Ciencias Sociales», Revista de Educación 353 (2010): 70.
} 
de adquisición de estas identidades son los discursos textuales e icónicos contenidos en los manuales escolares, que se conciben como fuente de autoridad y que pueden estar controlados por ideologías subyacentes. ${ }^{11}$

\section{FUENTES Y METODOLOGÍA DE ANÁLISIS}

La muestra escogida para el estudio está constituida por treinta manuales escolares pertenecientes a la fase desarrollista del franquismo, al periodo de la Transición y a los primeros años del periodo democrático. De este modo, la cronología de análisis de las fuentes comienza en los años sesenta y concluye en la primera mitad de la década de los ochenta, estableciéndose, como indicamos más arriba, una periodización por décadas (sesenta, setenta y ochenta). El análisis parte de esta periodización principal, pero dentro de cada década se establecen también determinados hitos históricos o legislativos relevantes que marcan diferencias sustanciales en los manuales. Así, la década de los sesenta se divide en dos fases delimitadas por la aprobación de los Cuestionarios Nacionales de 1965, que establecen una división legislativa con modificación de contenidos para la enseñanza primaria. En la década de los setenta, la muerte de Franco en 1975 y la aprobación de la Constitución en 1978 constituyen dos de esos grandes hitos. El objetivo de establecer esta periodización será descubrir de forma cronológica la evolución de los manuales y marcar diferencias o semejanzas, tanto en el diseño y la programación, como en el discurso y los contenidos.

El rango de edad al que van dirigidos los manuales seleccionados va de los once a los catorce años, ya que es el periodo escolar para el que se prescriben de forma directa los contenidos que pretendemos analizar. Una dificultad que se nos ha planteado a la hora de seleccionar los manuales surge de las modificaciones legislativas que se desarrollaron en el periodo analizado. Así, los manuales seleccionados para la década de los sesenta serían manuales de sexto grado del ciclo de perfeccionamiento de enseñanza primaria, y de séptimo y octavo grado de enseñanza primaria. Estos últimos dos cursos son añadidos con la Ley de Ampliación del Periodo de Escolaridad Obligatoria de

\footnotetext{
11 Atienza et al., «Identidad social», 67-106.
} 
1964. Con anterioridad a dicha Ley, esos cursos corresponderían al nivel no obligatorio del periodo de iniciación profesional, o al tercer o cuarto grado de bachillerato. Para las décadas de los setenta y ochenta hemos seleccionado manuales de sexto, séptimo y octavo curso de la Educación General Básica (EGB), instaurada por la Ley General de Educación de 1970 (LGE).

La necesidad de analizar aspectos basados en procesos económicos nos hizo recurrir a manuales relacionados con las Ciencias Sociales. De este modo, contemplamos para el análisis los contenidos de Geografía e Historia vinculados a las relaciones económicas, políticas y sociales. Siguiendo a Foucault, creemos que la Historia es un discurso histórico-político, ${ }^{12}$ el cual resulta relevante para esta investigación, lo mismo que aquellos contenidos de Geografía que revelan los procesos económicos. ${ }^{13}$ La escasez de manuales específicos de Geografía e Historia en la década de los sesenta hizo necesaria además la inclusión de algunos manuales de lecturas formativas históricas o geográficas, ya que muchas de esas lecturas disponían de contenido económico explícito y relataban los acontecimientos económicos y sociales más relevantes de aquella década. Por el contrario, en las décadas de los setenta y ochenta la enorme proliferación de manuales de Ciencias Sociales, debido al boom editorial de aquellos años, descartó la necesidad de recurrir a libros de lectura. De hecho, en los propios manuales se incluyen lecturas complementarias que aportan informaciones relevantes sobre los acontecimientos económicos, políticos y sociales.

\footnotetext{
12 Michel Foucault, Hay que defender la sociedad (Buenos Aires: Almagesto, 1992).

13 También hemos tenido en cuenta el criterio de Valls frente a las disciplinas de Geografía e Historia, pues según Valls han seguido la tendencia de «sobreestimar las continuidades histórico-cronológicas y a presentar el devenir histórico como algo natural, indiscutible y sin lagunas, fomentando una percepción legitimadora de lo existente, de lo finalmente triunfante», y estos son factores que pretendemos analizar. Rafael Valls, «Fuentes y referentes del saber escolar: los actuales manuales escolares (de historia) y criterios para su análisis y valoración», en Las competencias profesionales para la enseñanza-aprendizaje de las ciencias sociales ante el reto europeo y la globalización, ed. Rosa María Ávila, José R. López y Estibaliz Fernández (Bilbao: Asociación Universitaria de Profesores de Didáctica de las Ciencias Sociales, 2007), 503.
} 
Tabla 1. Criterios de selección de la muestra de manuales

\begin{tabular}{|c|c|}
\hline DÉCADA DE LOS SESENTA & DÉCADA DE LOS SETENTA Y OCHENTA \\
\hline Legislación: & Legislación: \\
\hline Ley de Educación Primaria 1945 & LGE 1970 \\
\hline $\begin{array}{l}\text { - Cuestionarios Nacionales para la } \\
\text { Enseñanza Primaria } 1953 \\
\text { - Cuestionarios Nacionales para la } \\
\text { Enseñanza Primaria } 1965 \\
\text { - Ley de Ampliación del Periodo de } \\
\text { Escolaridad Obligatoria } 1964\end{array}$ & $\begin{array}{l}\text { - Nuevas Orientaciones Pedagógicas de } \\
1971 \text { para la segunda etapa de la } \\
\text { Educación General Básica (E.G.B.) }\end{array}$ \\
\hline \multicolumn{2}{|c|}{ TIPOS DE MANUALES UTILIZADOS } \\
\hline $\begin{array}{l}\text { - Manuales de Geografía e Historia } \\
\text { - Manuales de Geografía } \\
\text { - Manuales de Historia } \\
\text { - Enciclopedias (Geografía e Historia) } \\
\text { - Lecturas (formativas, geográficas o } \\
\text { históricas) } \\
\text { - Educación Cívico-Social }\end{array}$ & $\begin{array}{l}\text { Área: Conocimiento del mundo social y } \\
\text { cultural. } \\
\text { - Manuales de Ciencias Sociales }\end{array}$ \\
\hline \multicolumn{2}{|c|}{ CURSOS } \\
\hline $\begin{array}{l}\text { - } 6^{\circ} \text { grado del ciclo de perfeccionamiento } \\
\text { de enseñanza primaria. } \\
\text { - } 7^{\circ} \text { y } 8^{\circ} \text { grado de enseñanza primaria } \\
\text { (cursos añadidos con la Ley de } \\
\text { Ampliación del Periodo de Escolaridad } \\
\text { Obligatoria de 1964). }\end{array}$ & $\begin{array}{l}\text { - } 6^{\circ} \text { curso de E.G.B. } \\
\text { - } 7^{\circ} \text { curso de E.G.B. } \\
\text { - } 8^{\circ} \text { curso de E.G.B. }\end{array}$ \\
\hline
\end{tabular}

Fuente: elaboración propia

En las fuentes se han analizado los conocimientos y valores, tanto técnicos como ideológicos, relacionados con los siguientes indicadores que consideramos determinantes en la configuración de identidades: la evolución económica de la dictadura, el tipo de desarrollo que se promovía, las representaciones del paisaje y del territorio, los procesos político-económicos llevados a cabo y las relaciones con Europa. Todo el proceso de análisis ha sido vinculado con el contexto socio-político, económico y educativo en el que los hechos fueron narrados, con el fin de contrastar y triangular los datos obtenidos del estudio de los manuales. Hemos considerado dichos contextos como relevantes, ya que las 
percepciones identitarias de cada sujeto o grupo se vinculan a las propias condiciones sociales de la época en la que se asientan. Este proceso puede ser uno de los motivos por los que las identidades son a menudo plurales y cambiantes. Consideramos también, en la línea de Weber, que el Estado necesita aunar voluntades en torno a sus valores ${ }^{14}$ y sentimientos identitarios, y uno de los mecanismos existentes para tal fin es la prescripción por parte del Estado de los contenidos educativos oficiales. Por ese motivo entendemos el sistema educativo como trasmisor de ideologías, identidades y mitos. ${ }^{15}$

El análisis de los discursos de los manuales ha incluido textos e imágenes, ${ }^{16}$ y se ha realizado a través de los estudios del lenguaje, el análisis semiológico, semántico y el análisis crítico del discurso (ACD). ${ }^{17}$ Hemos tenido en cuenta que las imágenes de los manuales son un elemento comunicativo que puede estar sujeto a lecturas que oscilan de lo denotativo a lo connotativo. En relación a lo connotativo, estaríamos considerando lo subjetivo (lo inconsciente), es decir, la interpretación de la realidad basada en la propia experiencia personal del que observa. Por otro lado,

\footnotetext{
14 Max Weber, El político y el científico (Madrid, Alianza, 1987).

${ }^{15}$ Emilio Castillejo trata la potencialidad de los mitos transmitidos en los manuales escolares de Historia del franquismo y su incidencia en la legitimación del orden social y en la promoción de ciertas identidades en su obra: Emilio Castillejo, Mito, legitimación y violencia simbólica en los manuales escolares de Historia del franquismo (1936-1975) (Madrid, UNED, 2008).
}

${ }^{16}$ El uso de las imágenes como fuentes sobre las que desarrollar estudios históricos se ha ido extendiendo y aceptando, aunque es cierto que presentan complejidad en su análisis. Partimos de la premisa de que toda producción visual asume la función de materializar representaciones, pero esta función está condicionada por el contexto del observador. Se ha de tener presente que para hacer una lectura correcta de las imágenes debemos tener en cuenta variables como el contexto, el texto y el código. Para saber más sobre el tema consultar: María del Mar del Pozo Andrés, «Imágenes e historia de la educación: construcción, reconstrucción y representación de las practicas escolares en el aula», Historia de la Educación. Revista interuniversitaria 25 (2006): 291-315; Ana María Badanelli, "Representing two worlds: illustrations in Spanish textbooks for the teaching of religion and object lessons (1900-1970)», History of Education 41, no. 3 (2011): 303-338; María del Carmen Sanchidrián Blanco, «El uso de imágenes en la investigación histórico-educativa», Revista de investigación educativa, RIE 29, no. 2 (2011): 295-310.

${ }^{17}$ En relación con este tema consultar: Emilio Castillejo, «Análisis del contenido ideológico de los manuales de historia», Bordón. Revista de pedagogía 61, no. 2 (2009): 45-58; Norman Fairclough, «El Análisis Crítico del Discurso como método para la investigación en Ciencias Sociales», en Métodos de análisis crítico del discurso, eds. Ruth Wodak, y Michael Meyer (Barcelona: Gedisa, 2003), 143178; Norman Fairclough, Critical discourse analysis (London: Longman, 1995); Norman Fairclough, Language and Power (London: Longman, 1989); Teun A. Van Dijk, «El análisis crítico del discurso», Anthropos 186 (1999): 23-36 y Teun A. Van Dijk, «Ideología y análisis del discurso», Estudio 29 (2005): 9-36. 
el discurso denotativo estaría asociado a lo objetivo (lo consciente), concibiendo la imagen como signo visual que sustituye a la realidad.

A través de los indicadores previamente establecidos en la investigación se han llevado a cabo operaciones como la exploración de presencias y ausencias, la disección racional y emocional del discurso, la jerarquización de contenidos, la identificación de dónde se ponen los énfasis, la adjetivación, el análisis de justificaciones, negaciones, proyecciones y discursos pantalla (políticamente correctos), etc.

\section{EL TIEMPO DE LA HISTORIA, EL ESPACIO GEOGRÁFICO Y LAS IDENTIDADES}

En la última fase del franquismo se produjeron notables cambios sociales, políticos y económicos que resultaron determinantes para España. Pérez Garzón afirma sobre el concepto de cambio, ${ }^{18}$ que este nos define como especie social, y por tanto, esa realidad de cambio nos sitúa, tanto de forma individual como colectiva, en la paradoja de la identidad y de la alteración. De este proceso se desprende la importancia de la Geografía, como ciencia de los distintos espacios humanos que no cesan de cambiar y, la disciplina de la Historia, como motor de cambio social.

La Geografía ha sido fundamental a la hora de propagar ideologías sobre el país al que se pertenece, pero también sobre los otros países. ${ }^{19}$ Esta disciplina posibilita el impulso de un sentimiento de pertenencia que guarda relación con un espacio concreto que se identifica con el modo de vivir y sentir cotidiano de un determinado país, región, cultura o lugar, configurando la identidad de los sujetos. Además, esa identidad surge de la relación dialéctica entre individuo y sociedad a lo largo de la historia. De esta forma, las culturas se cimentan sobre dos pilares fundamentales que quedan definidos en base al tiempo de la historia y al espacio geográfico. Por tales motivos, hemos atribuido a las disciplinas de Geografía e Historia la responsabilidad de configurarse como pilares

\footnotetext{
18 Juan Sisinio Pérez Garzón, «¿Por qué enseñamos Geografía e Historia? ¿Es tarea educativa la construcción de identidades?», Revista Historia de la Educación 27 (2009): 38.

19 María Teresa Benedito Sifre, Armando Cervellera Martínez y Xosé Manuel Souto González, «Los manuales escolares y la didáctica de la Geografía entre 1950 y 1990», en El libro escolar, reflejo de intenciones políticas e influencias pedagógicas, ed. Alejandro Tiana Ferrer (Madrid: UNED, 2000 ), 64.
} 
fundamentales sobre los que se estructuran las identidades sociales y nacionales, ${ }^{20}$ y es por eso que en este trabajo se han analizado dichas disciplinas desde la perspectiva del currículum y su extensión al discurso de los manuales.

En relación con las disciplinas de Geografía e Historia partimos de dos elementos, el paisaje y el territorio, que juegan un papel determinante en la configuración de la identidad (o identidades). Pérez Urraza et al. definen paisaje ${ }^{21}$ como

un espacio que se modifica a través del tiempo como consecuencia de la acción natural y humana. De ahí, que se considere también el paisaje cultural que se denomina al transformado por un grupo cultural a partir o desde un paisaje natural. La cultura es el agente, y el área natural donde se ejerce esa acción es el medio. El paisaje cultural es el resultado de esa transformación. ${ }^{22}$

Por lo tanto, entendemos el paisaje como elemento de los diferentes espacios que forman parte de procesos históricos y culturales, estando en continua transformación.

Por otro lado, el concepto de territorio ${ }^{23}$ fue ganando presencia en Geografía y otras Ciencias Sociales a partir de los años sesenta y setenta, utilizándose para hacer referencia al espacio de la soberanía o la jurisdicción de un país o sus unidades administrativas. El concepto se hizo especialmente relevante en Geografía Política, donde se fue cargando progresivamente de más contenido social, pasando a concebirse como espacio social y espacio vivido. ${ }^{24}$ De acuerdo con Horacio Capel,

\footnotetext{
${ }^{20}$ La Geografía y la Historia nacieron como disciplinas escolares en el siglo XIX, a la par que los Estados-nación, convirtiéndose en eficaces vehículos de los Estados para la creación de identidades nacionales.

${ }^{21}$ La Real Academia Española de la Lengua (RAE) define paisaje como «parte de un territorio que puede ser observada desde un determinado lugar».

${ }^{22}$ Karmele Pérez Urraza, Gurutze Ezkudia Arteaga y Begoña Bilbao Bilbao, «El paisaje: un concepto básico en el currículum desarrollado en los libros de texto del País Vasco», Espacio, Tiempo y Educación 2, no. 2 (2015): 225.

${ }^{23}$ La RAE define territorio como «porción de la superficie terrestre perteneciente a una nación, región, provincia, etc»..

${ }^{24}$ Horacio Capel, «Las ciencias sociales y el estudio del territorio», Revista bibliográfica de geografía $y$ ciencias sociales, Biblio3w 21, no. 1.149 (2016): 1 .
} 
Lo territorial se convierte así en el espacio vivido, modelado por el hombre, en función de sus necesidades. El territorio pasa a ser considerado como un producto social, una construcción social. Con elementos simbólicos que son creados por los hombres pero que, al mismo tiempo, tienen la capacidad de producir la identidad..$^{25}$

Del mismo modo que Rodríguez Lestegás, concebimos el territorio como construcción social, cultural y afectiva, ${ }^{26}$ pero también política, económica e histórica, donde se generan procesos de identidad, reproducción cultural, apropiación de la naturaleza, poder político-administrativo y mecanismos de transformación. El territorio está determinado por la reivindicación que despliega sobre el dominio del espacio y apropiación del terreno, imponiendo límites y fronteras. Beatriz Nates lo concibe también

como un escenario de poder, de gestión y de dominio del Estado, de individuos, de grupos y organizaciones y de empresas locales, nacionales y multinacionales, pero también como una superficie terrestre demarcada que conlleva una relación de posesión por parte de individuos y grupos y que contiene límites de soberanía, propiedad, vigilancia y jurisdicción. ${ }^{27}$

Esta concepción de Nates llevaría implícita una visión económica que resulta muy significativa, pues retrata al territorio como un escenario de poder, entre el que se encuentra el poder económico que deviene del poder político.

Hemos tenido también en cuenta el concepto de imaginario social, puesto que este haría referencia a discursos u objetos que han sido producidos socialmente y además institucionalizados como parte de la realidad. Su finalidad sería construir ejes intersubjetivos de comprensión grupal que permitan convenir o imponer la realidad. Por tanto, los imaginarios

\footnotetext{
25 Capel, «Las ciencias sociales y el estudio del territorio», 12.

26 Francisco Rodríguez Lestegás, «Territorialidad y pertenencia: la construcción geográfica de identidades", en Identidad y ciudadanía: reflexiones sobre la construcción de identidades, coord. Francisco Rodríguez Lestegás (Barcelona: Horsori, 2008), 144.

${ }_{27}$ Beatriz Nates Cruz, "Soportes teóricos y etnográficos sobre conceptos de territorio», Revista Co-herencia 8, no. 14 (2011): 211.
} 
sociales del territorio se configurarían como imaginarios grupales sobre espacios delimitados y apropiados simbólica y materialmente. Eso se concreta de manera especial en imágenes materializadas con fines de reproducción e institucionalización, sujetas a intereses concretos y relaciones de poder. En este sentido, un instrumento que ayuda a consolidar el imaginario social del territorio son las fotografías o imágenes que aportan los manuales. Los significados que promueven las imágenes como instrumento pedagógico pueden responder a la realidad, pero también a otras significaciones ideológicas y simbólicas, pues constituyen parte integrante del imaginario colectivo sobre una comunidad o territorio y pueden contribuir a la configuración de identidades.

\section{EL COMPONENTE ECONÓMICO EN LA CONFIGURACIÓN DE IDENTIDADES EN EL DESARROLLISMO FRANQUISTA, 1960-1975}

El régimen franquista utilizó la educación como instrumento para configurar una identidad nacional acorde con los valores del nacionalcatolicismo, a través de un discurso ideológico y propagandístico que se hizo muy visible en la primera fase del régimen, pero que estuvo presente hasta su final. De hecho, tales fueron las consecuencias y la herencia de este proceso que se advierten todavía estas derivaciones a nivel social, a través de lo que se ha venido denominando franquismo sociológico. ${ }^{28}$

El discurso de los manuales del primer franquismo llegaba a justificar una identidad nacional basada en el tradicionalismo moral, religioso y cultural, el recurso a la violencia, los viriles valores militares, el poder de cohesión de la Hispanidad y la exclusión de «los otros» (la Anti-España). ${ }^{29}$ En los años sesenta los manuales no abandonaron ese discurso, aunque este se fue moderando y transformando en función de las necesidades que imponía la realidad económica y social. El nuevo discurso, más funcional, se dirigía a justificar los procesos de modernización social y tecnológica que exigía el desarrollo económico del país, y por

\footnotetext{
${ }_{28}$ Algunas fuentes otorgan el término a Amando de Miguel, responsable en los años sesenta de los informes sociológicos de la Fundación Foessa. Consultar: Manuel Justel, «Edad y cultura política», Revista española de investigaciones sociológicas, REIS 58 (1992): 69.

29 Gregorio Cámara Villar, Nacional-catolicismo y Escuela. La Socialización Política del Franquismo, 1936-1951 (Jaén: Hesperia, 1984), 300.
} 
tanto, los procesos identitarios debían ser modificados en función de las necesidades del despegue económico.

España comenzó a restablecerse económicamente en los años sesenta como resultado de la apertura económica, la planificación (internacional), los Planes de Desarrollo, la inversión y el crédito extranjero, irrumpiendo de lleno en la economía de mercado, donde la adquisición de bienes materiales se convirtió en condición fundamental de la modernidad. Paradójicamente, el materialismo y el consumismo demonizados por el primer franquismo, se convirtieron en el sostenimiento y salvación del régimen. ${ }^{30}$ Rafael Abella señala al respecto que «la posesión de unos bienes propios, por modestos que fueran, trajo un cambio de mentalidad».31 Así comienza a configurarse un nuevo nacionalismo económico, que dejaba atrás el discurso sobre la nación espiritual y fundamentaba la cohesión nacional en base a la propia economía del país y su capacidad productiva. Esto suponía la transformación del imaginario colectivo, sustituyendo las imágenes de santos, mártires o héroes por nuevos símbolos desarrollistas (pantanos, industrias, grandes almacenes, etc.). El materialismo comenzó a integrarse en las esencias patrias, exaltando la fuerza de trabajo de la nación desde un plano material, vinculado a la capacidad de generar riqueza. El desarrollo económico y un nacionalismo español de base economicista quedaban fusionados en una nueva concepción del régimen, distanciada de la identidad nacional basada en la propaganda triunfalista y el discurso de la cohesión de la nación espiritual. Ahora la cohesión de la nación surgía a través de los logros económicos en una nueva concepción legitimadora del régimen.

Asimismo, el régimen se proclamó en los años sesenta garante de la paz, que dio paso al proceso desarrollista y al resurgimiento de España como Nación aceptada internacionalmente. Los rasgos iniciales impuestos por la dictadura, y que conferían unidad al sistema, debían moderarse para poder ser adaptados a los cambios sociales y nuevos condicionamientos de la dinámica económica, adaptando también los procesos identitarios a las necesidades del proceso modernizador y del despegue económico. Para tal fin era

\footnotetext{
30 José Luis García Delgado, «La economía», en Franquismo. El juicio de la historia, ed. José Luis García Delgado (Madrid: Temas de hoy, 2000).

${ }_{31}$ Rafael Abella, La vida cotidiana en España bajo el régimen de Franco (Barcelona: Argos Vergara, 1985), 196.
} 
necesario «integrar a los trabajadores dóciles en el orden capitalista». ${ }^{32} \mathrm{El}$ desarrollismo necesitaba optimismo, motivación y armonía social, y para eso había que abandonar el discurso belicista inicial de los manuales para abrazar el de la paz de Franco y el progreso. Una paz que incurría en la pasividad y el conformismo, donde la ciudadanía debía volcarse en trabajar por el desarrollo del país ${ }^{33}$ eludiendo el conflicto y manteniendo el orden establecido, pues «la sociedad requiere que cada uno de sus componentes se esfuerce en servir a la comunidad con su trabajo». ${ }^{34}$

López Facal ya señaló que la versión nacionalcatólica del nacionalismo español se basaba en el organicismo y el historicismo, ${ }^{35}$ pero en este trabajo apuntamos también hacia una asociación del relato ideológico, identitario y nacionalista con la esfera económica, es decir, partimos de la idea de que la esfera económica tiene capacidad de configurar nuevas concepciones identitarias. De hecho, en la primera fase del franquismo el régimen justificaba la autarquía económica como proyecto ideológico que le proveería de independencia política. ${ }^{36}$ Así lo describía un manual de lecturas de 1943:

El jefe del Estado es, además de tal, generalísimo de las fuerzas de tierra, mar y aire. La religión Católica vuelve a ocupar el alto lugar que le corresponde por su misión histórica y civilizadora, y España se halla de nuevo en la senda imperialista que nunca debía haber abandonado, esperando hacerse fuerte y dueña de sus destinos, gracias a una patriótica autarquía y a la unión de todos los españoles. ${ }^{37}$

En la segunda fase, la desarrollista, la esfera económica también sirvió a una nueva concepción del nacionalismo franquista, donde los logros económicos proporcionaban una nueva legitimidad al régimen y a

\footnotetext{
32 Boyd, «De la memoria oficial a la memoria histórica», 95.

33 José Sánchez Jiménez, «La España de los 'sesenta'. La recepción y las influencias de la 'Pacem in Terris' en una sociedad en vías de desarrollo», Sociedad y Utopía. Revista de Ciencias Sociales 42 (2013): 119

${ }^{34}$ Alfredo Gosálbez Celdrán, Educación Cívico-Social 6º (Madrid: Doncel, 1969 [2ª edición]), 7.

35 Ramón López Facal, «El nacionalismo español en los manuales de Historia», Educació i Història. Revista d'Història de l'educació 2 (1995): 125.

${ }^{36}$ Lino Camprubí Bueno, Los ingenieros de Franco. Ciencia, catolicismo y Guerra Fría en el Estado franquista (Barcelona: Crítica, 2017).

${ }_{37}$ Pilar Pascual de San Juán, Flora. La educación de una niña (Barcelona: Paluzie, 1943), 342.
} 
sus políticas. Este hecho puede observarse en el siguiente ejemplo de un manual del año 1967:

El progreso industrial ha sido notable en los últimos años en la fabricación de vehículos, siderurgia e industrias textil y química. En 1963 el Gobierno dispuso la creación de un Plan de Desarrollo económico y social, y de Polos de desarrollo, en las regiones del Centro, Andalucía y Galicia, menos industrializadas..$^{38}$

Como se observa en el ejemplo, y como cabría esperar de la propaganda de la dictadura, la responsabilidad de los logros económicos recae únicamente sobre el Gobierno franquista. Pero el discurso económico de los manuales de los sesenta no revela las cuestiones negativas que acompañaron al desarrollo, como la pobreza, el paro, la emigración ilegal, el lamentable estado de la educación, etc..$^{39}$ Este hecho denotaría el fomento de una identidad compatible con el discurso del crecimiento y desarrollo económico desde una perspectiva sesgada, pues la reflexión autocrítica no sería compatible con una pretendida transmisión de adoctrinamiento nacionalista. ${ }^{40}$ Entendemos que la ideología desarrollista del franquismo estaba estrechamente vinculada con la promoción de una identidad nacionalista controlada propagandísticamente, a través de una autoimagen positiva del desarrollo de España. Por esa razón, un hecho muy significativo es la imagen que promueven los manuales sobre los logros económicos del régimen, desvinculada de la planificación del bloque occidental, y de las prescripciones de los organismos internacionales como el Banco Mundial, el Fondo Monetario Internacional, la UNESCO, etc. Esta estrategia propagandística que mostraban los manuales, de responsabilizar únicamente a las políticas del régimen del «milagro económico español», servía también para justificarlo y legitimarlo. El mito de los orígenes, ${ }^{41}$ basado en la victoria en la Guerra Civil, deja de ser válido, para dar paso a otro principio legitimador de base

\footnotetext{
38 Mariano Ojuel Gómez, Geografía e Historia 6º (Barcelona: Prima Luce, 1967), 217-218.

${ }_{39}$ Castillejo, Mito, legitimación y violencia simbólica, 513.

40 Atienza et al., «Identidad social», 99.

${ }^{41}$ Ismael Saz Campos, «Fascism, Fascistization and Developmentalism in Franco's Dictatorship», Social History 29, no. 3 (2004): 352-353; Paloma Aguilar Fernández, Memoria y olvido de la Guerra Civil española (Madrid: Alianza Editorial, 1996); Juan Linz, «Legitimacy of Democracy and the Socioeconomic System», en Comparing Pluralist Democracies. Strains on Legitimacy, ed. Mattei Dogan (London: Westview Press, 1988), 92; Juan Pablo Fusi, «La cultura», en Franquismo. El juicio de la historia, ed. José Luis García Delgado (Madrid: Temas de hoy, 2000), 219-295.
} 
economicista que favorece la configuración de identidades basadas en una autoimagen positiva de España. Veamos un ejemplo: « [...] España ha logrado vencer las dificultades y se ha superado a sí misma, contribuyendo en la tarea común de todos los españoles. ¿Qué es lo que ha permitido este avance económico o industrial? Un plan y el trabajo de todos coordinado por el Gobierno de la nación». ${ }^{42}$ La asimilación del discurso en exceso optimista y grandilocuente promovido por los manuales de los años sesenta impide la no identificación de los sujetos con ese nacionalismo de base economicista, generando una percepción de la realidad acorde con el discurso positivo, favorecedor de representaciones sociales sobre la identidad nacional.

Como expusimos anteriormente, un elemento que analizamos para estudiar la configuración de nuevas identidades es el paisaje, por su importante papel en el proceso de formación, consolidación y mantenimiento de las identidades territoriales. ${ }^{43}$ Con el «boom económico» de los años sesenta el paisaje de España se transformó de forma muy intensa y rápida, lo que conduciría a una pérdida de valores simbólicos tradicionales para adoptar otros nuevos, asociados a la modernidad y al desarrollo. Los paisajes rurales tradicionales fueron sustituidos por los paisajes metropolitanos y de turismo de masas, materializándose una metropolización del territorio sin control, con la construcción de grandes infraestructuras (polígonos industriales, grandes ciudades, ciudades turísticas, pantanos, etc.) que transformaron la identidad de muchos lugares. ${ }^{44} \mathrm{El}$ imaginario social vinculado al territorio se fue reformulando con la aparición de nuevos modelos de urbanismo distintos a los tradicionales, nuevos patrones de ocupación del suelo, consolidación de núcleos urbanos, estrechamiento del límite entre el campo y la ciudad, etc. Todos estos procesos ejercieron un fuerte impacto capaz de influenciar las concepciones identitarias de la población.

\footnotetext{
42 Gosálbez, Educación Cívico-Social 6º 168.

${ }_{43}$ M. J. Bajo Bajo, «El paisaje en el currículum de Educación Primaria, dentro del área del conocimiento del medio natural, social y cultural», Aula 13 (2001): 52; Joan Nogué, «Nacionalismo, territorio y paisaje en Cataluña», en Paisaje, memoria histórica e identidad nacional, ed. Nicolás Ortega Cantero (Madrid: Universidad Autónoma de Madrid y Fundación Duques de Soria, 2005), 147-169; María del Carmen Morón Monge, Hortensia Morón Monge y Jesús Estepa Giménez, «El paisaje en el currículum oficial y los libros de texto de Ciencias Sociales de la ESO: una perspectiva patrimonial integral», en Actas I Congreso Internacional de Educación Patrimonial: Mirando a Europa: estado de la cuestión y perspectivas de futuro (Madrid: IPCE, 2012), 564-573.

${ }^{44}$ Joan Nogué, «Territorios sin discurso, paisajes sin imaginario. Retos y dilemas», Ería 73-74 (2007): 374.
} 


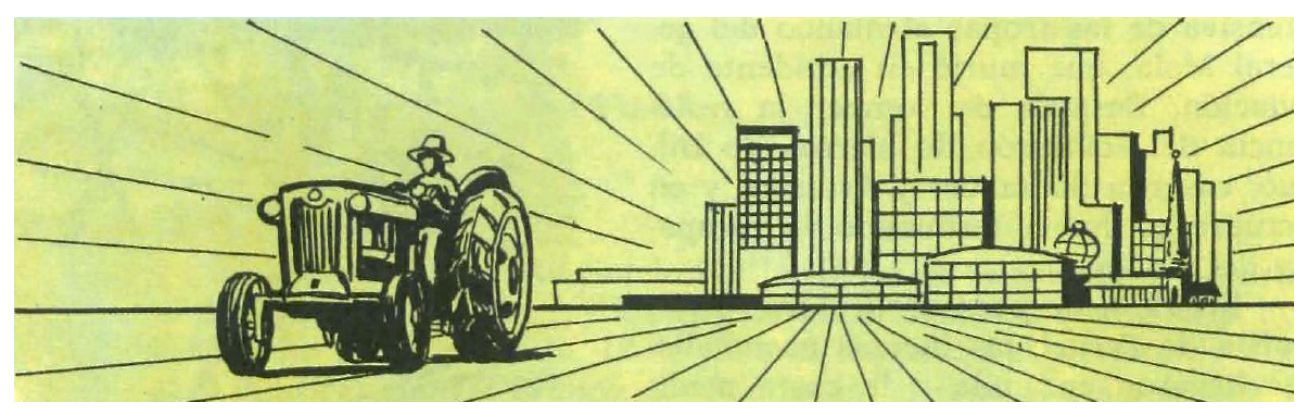

Imagen 1. Geografía e Historia 6 ${ }^{\circ}$ 1967: «La reconstrucción de España».45

El nuevo paisaje que se representaba en los manuales de los años sesenta evidenciaba una realidad física que impulsaría una representación cultural nueva, alejada de la España agraria profundamente atrasada. La construcción de este nuevo imaginario vinculado al territorio orientaba una nueva percepción de la realidad de un país que salía del subdesarrollo, supuestamente gracias a las políticas económicas del régimen. Esta nueva estrategia de legitimación del régimen, que pasaba por estereotipar el imaginario desarrollista, formaría parte de un proceso de socialización del paisaje impulsado por el poder. Una especie de alegoría de una nueva España, que consolidó un imaginario colectivo, compartido y socialmente aceptado. Desde este trabajo defendemos que dicho imaginario ha formado parte de un registro ideológico, identitario y político, incorporando a la simbología estos paisajes estereotipados del desarrollo franquista. No olvidemos que el conocimiento que difunden los manuales es considerado legítimo por la sociedad, ${ }^{46}$ asumiéndolo como único posible y verdadero. ${ }^{47}$

Las imágenes de esos nuevos paisajes se configuran como símbolos identitarios modernos del territorio. Uno de esos símbolos serían las presas y pantanos que comenzaron a aparecer de forma masiva en los manuales, conformando un imaginario de la modernidad franquista claramente reconocible hasta en la actualidad. ${ }^{48}$

\footnotetext{
45 Ojuel, Geografía e Historia, 216.

46 Michael Apple, «El libro de texto y la política cultural», Revista de Educación 301 (1993): 116.

47 Pérez, «El paisaje», 227.

48 El franquismo sociológico asimila como uno de los grandes hitos del franquismo la construcción de presas y pantanos como mecanismos facilitadores del desarrollo y del «milagro económico».
} 


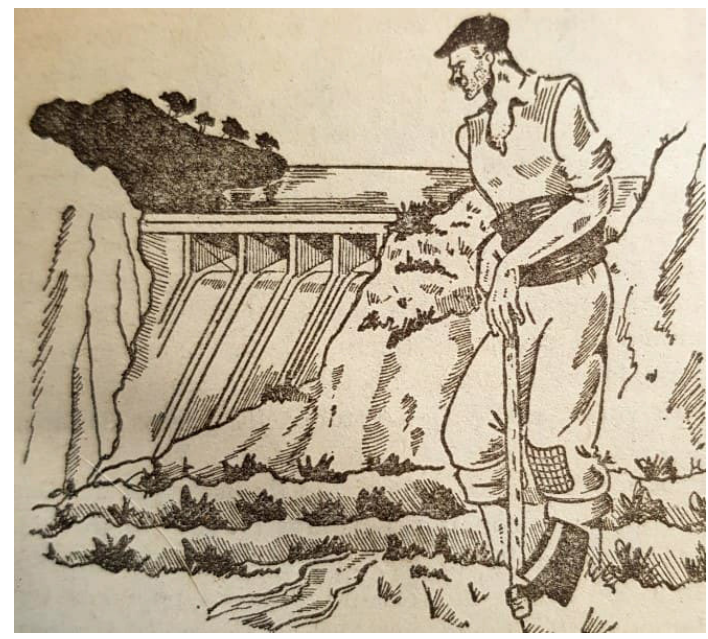

Imagen 2. Nuevos símbolos desarrollistas. Manual de lecturas, $1963 .{ }^{49}$

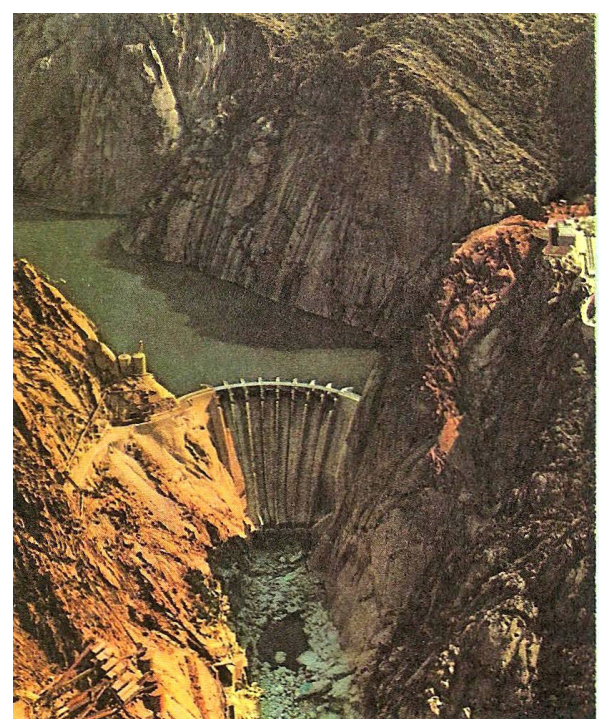

Imagen 3. Nuevos símbolos desarrollistas. Manual de Ciencias Sociales, $1974 .{ }^{50}$

Pero no solo el discurso de las imágenes configuró ese nuevo imaginario, sino que el discurso textual que las acompañaba también recreaba la

\footnotetext{
49 Leónides Gonzalo Calavia (dir.), Ahora. La actualidad en lecturas formativas para escolares de 10 a 12 años (Madrid: Paraninfo, 1963), 41.

50 Julián Abad et al., Consultor. Ciencias Sociales $8^{\circ}$ (Madrid: Santillana, 1974), 474.
} 
concepción de un modelo de territorio asociado a la esfera económica, mostrando una España ideal llena de potencialidades.

[...] España está aumentando sin cesar sus riquezas, repoblando sus bosques, mejorando su agricultura con nueva maquinaria y nuevos cultivos; abriendo fábricas, fundando nuevos pueblos, enviando sus productos naturales y manufacturados a los grandes mercados del mundo; acogiendo en su seno a los sabios que se reúnen en Congresos Internacionales; mandando a sus hombres más eminentes a los más acreditados centros de investigación $\left[\ldots . . .^{51}\right.$

[...] especialmente desde el final de la guerra, en 1939, se han llevado a cabo en España numerosas obras, adoptando todos los progresos de la técnica actual.

Se han construido multitud de embalses, que han beneficiado a la agricultura, pues permiten regar grandes extensiones de tierras que antes eran muy pobres por la falta de agua. Los embalses han servido también para construir grandes centrales eléctricas, que a su vez han permitido desarrollar la industria. ${ }^{52}$

De este modo, los contenidos curriculares se convirtieron en recurso para la configuración de identidades culturales modernas, a través de una nueva concepción del paisaje asociada al desarrollo que llegó a conformarse como concepto curricular. ${ }^{53}$ Este hecho se afianza a partir de 1965 cuando se aprueban los nuevos Cuestionarios Nacionales para la enseñanza primaria. ${ }^{54}$ Con ellos se pretendía adaptar la educación primaria a la nueva sociedad desarrollista. ${ }^{55}$ Este ajuste atiende legalmente al poder económico que marcaba el desarrollo del país, para adaptar la educación a las necesidades de esa España en desarrollo que necesitaba mano de obra cualificada. Por tanto, la educación quedaba

\footnotetext{
${ }^{51}$ Agustín Serrano de Haro, Mirando a España (Madrid: Paraninfo, 1963), 90.

52 Rosa Ortega, Historia (Barcelona: Teide, 1965), 51.

${ }^{53}$ Pérez, «El paisaje», 225-242.

${ }_{54}$ «Orden de 8 de julio de 1965 por la que se aprueban los cuestionarios que han de regir todas las actividades didácticas en las Escuelas Primarias», Boletín Oficial del Estado (BOE) no. 229 (24 de septiembre de 1965): 13006-13065.

55 «Orden de 8 de julio de 1965 por la que se aprueban los cuestionarios», 13006.
} 
supeditada al desarrollo económico y al servicio del poder. El inspector de educación Abad Asenjo declaraba en un curso ofrecido por el Servicio Español del Magisterio en 1966 lo siguiente: «[...] nos urge poner a punto nuestra niñez y juventud para implicarlas enseguida en el plan de desarrollo económico y social español que está en marcha. Esta es ya una faceta que recogen ampliamente nuestros cuestionarios». ${ }^{56}$

Pero los manuales escolares de la década de los sesenta mostraban también una amalgama de los antiguos y nuevos símbolos, complementados con discursos que alababan las políticas del régimen en materia económica. Un ejemplo sería la Enciclopedia Dalmau, donde aparece una ilustración del VICTOR, ${ }^{57}$ convertido para el franquismo en emblema de la victoria en la Guerra Civil. Tras el símbolo, sigue habiendo alusión directa a la victoria, aunque ahora se compatibiliza con una alusión a la paz y al progreso que auspiciaban un magnífico futuro a la nación, pues el VICTOR se muestra rodeado de las mejoras técnicas implementadas en el campo (tractores y maquinaria agrícola) y el desarrollo industrial (fábricas). Esta imagen revela que pese a que todavía se utiliza el principio legitimador inicial del régimen basado en la victoria, ya comienza a establecerse un nuevo principio basado en los logros del caudillo para con el progreso de la nación y la garantía de la paz. Como afirman Badanelli y Del Pozo, «las imágenes son un potente instrumento para transportar las representaciones simbólicas de la identidad nacional española», ${ }^{58}$ y en ese sentido, las imágenes del desarrollo español mostradas de forma continuada en los manuales pueden provocar también este efecto, en cuanto son utilizadas como símbolo de una industrialización redentora que fue denominada «milagro económico».

\footnotetext{
${ }_{56}$ Andrés Abad Asenjo, «Cuestionarios y programas de Enseñanza Primaria», Revista de Educación 184, (1966): 57.

57 Dalmáu, Enciclopedia Estudio. Libro azul. Ciclo Perfeccionamiento (Gerona/Madrid: Dalmáu, 1963), 739.

58 Ana María Badanelli y María del Mar del Pozo, «Desde la madre-patria española al Estado de las autonomías: la idea de España en los manuales escolares (1900-2007)», Historia de la educación 27 (2008): 397.
} 


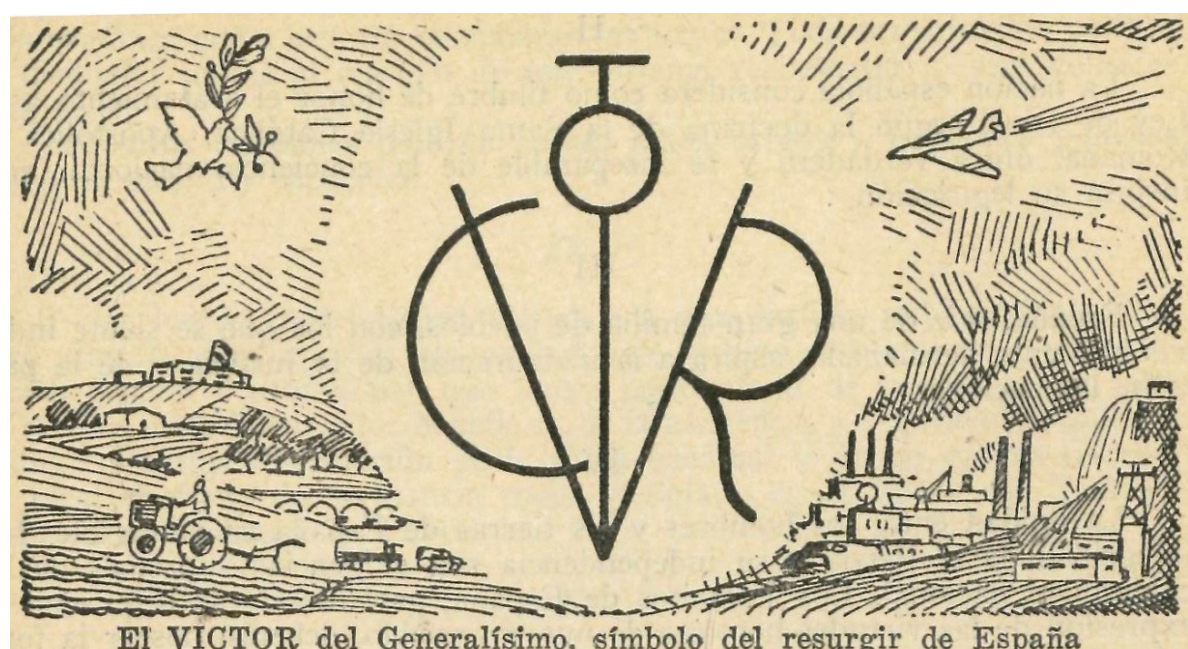

Imagen 4. «El VICTOR del Generalísimo, símbolo del resurgir de España». Enciclopedia Estudio. Libro azul, $1963 . .^{59}$

\section{EL COMPONENTE ECONÓMICO EN LA CONFIGURACIÓN DE IDENTIDADES EN LA TRANSICIÓN A LA DEMOCRACIA, 1975-1985}

Ya desde la aparición de la LGE de 1970 se empezaron a vislumbrar nuevas perspectivas para las Ciencias Sociales, pues la educación debía ajustarse a los importantes cambios que se estaban fraguando en España. La Ley promovía aspectos como el desarrollo de aptitudes para la convivencia, el sentido cívico-social y de pertenencia a las diversas comunidades (local, nacional, europea, e internacional), ${ }^{60}$ sembrando expectativas para la configuración de nuevas identidades sociales. La LGE se concretó en las nuevas Orientaciones Pedagógicas para la EGB, ${ }^{61}$ que fueron publicadas en la Revista Vida Escolar, ${ }^{62}$ apuntando cambios

\footnotetext{
59 Dalmáu, Enciclopedia Estudio, 739.

${ }^{60}$ Alejandro Mayordomo, «Regenerar la sociedad, Construir el Patriotismo o la Ciudadanía: Educación y Socialización Política en la España del siglo XX», Encounters in Theory and History of Education 1 (2008): 73; Cecilia C. Milito Barone, «Conflicto y convivencia en el discurso pedagógico oficial durante el tardofranquismo y la Transición democrática española (1965-1982)» (Tesis doctoral, UNED, 2019).

${ }_{61}$ «Orden de 2 de diciembre de 1970 por la que se aprueban las orientaciones pedagógicas para la Educación General Básica», Boletín Oficial del Estado (BOE) no. 293 (8 de diciembre de 1970): 19966.

${ }^{62}$ Dirección General de Ordenación Educativa, «Orientaciones Pedagógicas para la EGB», Revista Vida Escolar 124-126 (1970-71).
} 
significativos en cuanto a contenidos, valores y métodos. Respecto a la segunda etapa de la EGB, en el Área Social y Cultural, se advertía la confluencia de la Geografía y la Historia, añadiendo expresamente aspectos de economía, sociología, antropología y política: ${ }^{63}$ «El área social y cultural tiene como objeto el estudio del hombre: formas de vida, agrupación, relaciones económicas, políticas y sociales, inquietudes ideológicas y expresión cultural». ${ }^{64}$

Bajo la perspectiva de la LGE podemos afirmar que, en líneas generales, los manuales de mediados de los setenta y comienzos de los ochenta se presentan más críticos y objetivos con respecto al discurso del desarrollo económico de los años sesenta, señalando incluso algunas deficiencias del proceso que habían sido anteriormente ocultadas. Esto se observa en el texto de un manual de Vicens Vives del año 1978 que dice: «[...] los problemas que se plantean en las grandes ciudades, a donde llegan constantemente gentes, [...] que necesitan viviendas, escuelas, transportes urbanos, asistencia médica y religiosa. Son problemas muy graves, que exigen para ser resueltos una planificación muy cuidada, que no han tenido».65 Veamos también este otro ejemplo de un manual del año 1981 de la editorial SM:

Las auténticas razones de este gran desarrollo económico hay que buscarlas, no en los Planes de Desarrollo, sino en el turismo, las remesas de los emigrantes y las inversiones extranjeras.

[...] El desarrollo industrial español de los años sesenta agravó las diferencias regionales ya existentes. La inversión se centró en las zonas que ya tenían una infraestructura adecuada [...]. Pero esta política ha provocado, en los últimos veinte años, un continuo trasvase de mano de obra, capitales y materias primas de las regiones pobres a las ricas, lo que puede calificarse de auténtico colonialismo interior. ${ }^{66}$

\footnotetext{
${ }^{63}$ Mayordomo, «Regenerar la sociedad, Construir el Patriotismo o la Ciudadanía», 74.

${ }^{64}$ Dirección General de Ordenación Educativa, «Orientaciones Pedagógicas para la EGB», 40.

65 Antonio Fernández García, Montserrat Llorens Serrano y Rosa Ortega Canadell, Historia Contemporánea. Orbe-País. $8^{\circ}$ curso de EGB (Barcelona: Vicens Vives, 1978) [4ª edición], 266.

66 Juan José Fernández Sanz y Gabriel García Voltá, Mundo y Sociedad $8^{\circ}$ egb (Madrid: SM, 1981), 248-249.
} 
Por otro lado, los contenidos relacionados con la esfera económica se incrementan de forma especialmente llamativa, tecnificándose y adquiriendo un enorme protagonismo dentro de los contenidos. Un ejemplo significativo sería un manual de Santillana de 1974, que circulaba en las aulas antes de la muerte del dictador. En él encontramos un apartado introductorio que hace referencia a la democracia, las elecciones, y a su vez, al funcionamiento de los bancos, presentando una conexión directa entre economía, política y circunstancias sociales:

Y si ninguna época pasada puede entenderse prescindiendo de sus manifestaciones políticas y económicas, tampoco la época que nos ha tocado vivir podría entenderse sin una profundización en sus aspectos más esenciales y más superficiales a la vez, en su realidad político-económica concreta. ¿Qué tipos de regímenes políticos existen en la actualidad? ¿Cuáles son las características de una democracia? ¿Qué diferencias hay entre el sistema económico capitalista y el socialista? ¿Por qué hay países desarrollados y países subdesarrollados? O, descendiendo ya a la vida práctica de todos los días: ¿Qué función desempeña el ahorro? ¿Cómo funcionan los Bancos? ¿Cuál es el mecanismo de las elecciones?

A todos estos interrogantes, fundamentales para participar conscientemente en la vida de las actuales sociedades, responden la ciencia política y la ciencia económica. ${ }^{67}$

Durante el periodo de decadencia final del régimen el discurso oficial de la nación se disociaba cada vez más del discurso real que vivía la sociedad española. ${ }^{68} \mathrm{El}$ programa desarrollista de los tecnócratas del régimen, que tenía también como propósito un cierto desarrollo político, pero sin salir del autoritarismo de la dictadura, ${ }^{69}$ resultaba agotado para la sociedad de principios de los setenta y para una clase media con unos niveles de riqueza y consumo aceptables. La esencia de la españolidad estaba ahora relacionada con la capacidad productiva y de consumo,

\footnotetext{
${ }^{67}$ Abad, Consultor. Ciencias Sociales 8, 11.

68 Lara Campos, Los relatos de la nación. Iconografía de la idea de España en los manuales escolares (1931-1983) (Madrid: Centro de Estudios Políticos y Constitucionales, 2010), 257.

${ }^{69}$ Antonio Cañellas Mas, «La tecnocracia franquista: el sentido ideológico del desarrollo económico», Studia Histórica. Historia contemporánea 24 (2006): 257-288.
} 
perdiéndose en gran medida la sacralidad para acabar consolidándose un nacionalismo más banal, ${ }^{70}$ asociado al bienestar económico, la productividad, la modernidad y el consumo. Observemos un ejemplo de un manual de 1974 de la editorial Magisterio Español:

El resultado de esta evolución económica ha sido la elevación del nivel de vida de los españoles; como consecuencia de este aumento del nivel de vida han sufrido una transformación sus costumbres, aficiones, diversiones, y cultura. Se percibe la elevación del nivel de vida en el urbanismo, en la decoración de la vivienda de la que se preocupan todas las clases sociales, en el vestido, en las diversiones. Las vacaciones y la práctica cada vez más extendida del deporte son manifestaciones del aumento del nivel de vida.

El uso de electrodomésticos se ha generalizado; el III Plan de Desarrollo prevé que todas las familias dispondrán de teléfono, televisor, vivienda y, ocho de cada diez de automóvil. ${ }^{71}$

Bernecker nos recuerda que en procesos rápidos de transformación de mentalidades, como el acontecido en España, la cultura autóctona y sus costumbres arraigadas suelen ser materia de especial trascendencia, puesto que se presentan como elementos invariables frente a los nuevos valores trasformadores. ${ }^{72}$ De este modo, el elemento identitario español que había representado la religión dentro del discurso de los manuales no desapareció, pero fue perdiendo cada vez más protagonismo. Como afirma Lara Campos,

ahora tenía que disputar su espacio de influencia con las nuevas esencias que se le habían encontrado al ser español: su capacidad productiva (a través de un trabajo constante y abnegado), su capacidad de consumo (a través de la adquisición de una serie de productos básicos para las clase medias, como televisores,

\footnotetext{
${ }^{70}$ Michael Billing, «El nacionalismo banal y la reproducción de la identidad nacional», Revista Mexicana de sociología 1 (1998): 37-57. Este concepto alude a un nacionalismo menos sacralizado y más ligado a la cotidianidad de la ciudadanía.

${ }^{71}$ Luis Coronas Tejada, Mundo y sociedad 8º (Madrid: Magisterio Español, 1974), 264.

72 Walter L. Bernecker, «The change in mentalities during de late Franco Regimen», en Spain transformed. The late Franco Dictatorship, 1959-1975, ed. Nigel Townson (Nueva York: Palgrave McMillan, 2007), 67-84.
} 
automóviles o viviendas en propiedad) y su capacidad para entusiasmarse con los espectáculos de masas, (como el fútbol y otros deportes). ${ }^{73}$

La Transición comienza tras la muerte del dictador en 1975. Fue entonces cuando se pudo recuperar el debate sobre la pluralidad de versiones políticas y las múltiples realidades nacionales, que con anterioridad habían sido duramente perseguidas por la dictadura. Tras cuatro décadas de dictadura se hizo posible recuperar la costumbre dialéctica entre las diferentes concepciones de una misma nación. Dos modelos enfrentados aparecieron en los debates públicos. Por un lado, un discurso conservador y centralista asociado a los mecanismos del régimen, y por otro, un discurso de la izquierda basado en la necesidad de primar los valores universales de Occidente, donde el centralismo fue sustituyéndose por una voluntad descentralizadora. Este último discurso, llevaba implícito el reconocimiento de las múltiples identidades que conformaban el Estado español, y que la dictadura había pretendido sofocar. ${ }^{74}$

El propósito de los conservadores seguía siendo una España única e indivisible. Consideraban que las regiones históricas o nacionalidades no disponían de rasgos identitarios característicos, diferenciados de los que ellos asumían como propiamente españoles, adscribiéndose así a posturas que no distaban mucho en esencia de la visión del nacionalismo concebido por el régimen franquista. Las diferencias regionales eran contempladas más bien como elementos folclóricos y culturales.

En otra posición bien distinta, la concepción sobre la nación que tenía la izquierda se amparaba en una clara voluntad descentralizadora y, por tanto, respaldaba ciertos rasgos identitarios de carácter regional. La nueva propuesta se basaba en la construcción de un nuevo modelo de Estado que finalmente quedó configurado como un Estado de las Autonomías. Estas posturas contrapuestas generaron un importante debate a la hora de redactar la Constitución de 1978, aunque finalmente la Carta Magna logró fundamentarse, en su artículo II, en la indisoluble unidad de España reconociendo el derecho a la autonomía de las nacionalidades

\footnotetext{
73 Campos, Los relatos de la nación, 259.

74 Isidro Sepúlveda, «La eclosión nacionalista: regionalismos, nacionalismos y autonomías», en Historia de la Transición (1975-1986), ed. Javier Tusell y Álvaro Soto (Madrid: Alianza, 1996), 409-443.
} 
y regiones que la integran. Como consecuencia de ello se crearon las Comunidades Autónomas, a las que se traspasarían una serie de competencias administrativas.

Una vez aprobada la Constitución, los manuales comenzaron a modificar su discurso en base a la fórmula que promovía el artículo II, reflejando la nueva unidad de España con su diversidad autonómica. Los nuevos programas diseñados para las Ciencias Sociales consideraron el estudio de lo local y regional desde una perspectiva más política y económica. También se diseñaron e implementaron temas específicos de Educación Ética y Cívica, dentro de los contenidos de Ciencias Sociales, para tratar de abordar el nuevo concepto de nación, donde se presentaban las nuevas leyes y todo lo referente al nuevo sistema de gobierno democrático, sus instituciones y sus estructuras administrativas. Veamos un ejemplo del año 1984:

\section{España: Unidad en la diversidad}

España es un Estado democrático. «La Constitución se fundamenta en la indisoluble unidad de la Nación española [...] y reconoce el derecho a la autonomía de las nacionalidades y regiones» (art. 2 de la Constitución española).

Este texto constitucional contiene dos importantes enseñanzas:

a) España es una unidad política y económica. En todo el territorio nacional rigen las mismas leyes mercantiles y leyes penales y la misma moneda. Todos los españoles tienen unos mismos derechos y deberes reconocidos en la Constitución. Un mismo Gobierno -el Gobierno del Estado- dirige la defensa nacional y las relaciones de España con otros países. El Rey es el jefe del Estado y el símbolo de su unidad.

b) En España hay una parte del poder político que se distribuye territorialmente entre las diversas Comunidades Autónomas. Cada Comunidad Autónoma puede no sólo administrar de forma descentralizada una parte de los recursos nacionales, sino también autogobernarse, con ciertos límites que impone la Constitución, en numerosas materias: cultura, educación, sanidad. etc. 
Por ello es justa la expresión que define a España como Estado de las autonomías. ${ }^{75}$

La imagen que ofrecen ahora los manuales es la de una España como nación rica y variada pero única, es decir, una pero diversa. Así se incidía en el estudio tanto de lo local o regional como en lo nacional, dentro del nuevo Estado de las Autonomías.

Además de la identidad nacional, los manuales legitiman también otros tipos de identidades, normalmente compatibles con la nacional. Estaríamos hablando por ejemplo de la identidad occidental, la identidad europea, la cristiana, la catalana, vasca, gallega, castellana, etc. La identidad occidental derivaría de la vertiente cultural, que se afianzaría al invocar un pasado antiguo común. Del factor religioso surgiría la identidad cristiana, que se fomentaría a través del relato que sostiene el compartir el cristianismo como origen cultural. De hecho, las editoriales principalmente católicas inciden presentando en su discurso la naturaleza cristiana de Occidente, o la naturaleza católica de España. Lo mismo ocurre con la esfera socioeconómica, donde occidente se asocia indefectiblemente al sistema capitalista desde la Revolución industrial. Veamos un ejemplo de un manual de SM del año 1978:

El equilibrio del mundo de hoy se basa en su escisión en dos grandes bloques de pueblos:

- uno de tradición grecorromana, cristiana, humanista y democrática, en torno al Atlántico y regido por los EE.UU.;

- el otro formado de naciones, religiones y razas distintas, de tradición autoritaria y colectivista, en torno a la U.R.S.S. ${ }^{76}$

De este modo, a través de dichas asociaciones se le estaría privando a la identidad occidental de otras muchas responsabilidades, por ejemplo del ateísmo, del marxismo, de la contracultura, etc. ${ }^{77}$

\footnotetext{
75 Pablo Castejón, José Luis Díez y Jaime Mascaró, Sociedad 8 (Madrid: Santillana, 1984), 214. Las negritas y cursivas son del original.

${ }^{76}$ Juan Rastrilla Pérez et al., Historia Universal y de España 8 (Madrid: SM, 1978), 83. Las negritas son del original.

77 Emilio Castillejo Cambra, «Indicaciones sobre la investigación. Ciudadanía, identidades complejas y cultura política en los manuales escolares españoles (1978-2006)», Documento de trabajo
} 
En los manuales podemos encontrar la identidad europea a través de dos versiones diferentes, una asociada al eurocentrismo y otra asociada al europeísmo. La visión eurocéntrica es una versión de la historia acrítica, configurada desde el propio punto de vista europeo. Esta visión se configuraría a través de la ocultación o atenuación de todos aquellos aspectos negativos que conlleva el relato, y potenciaría únicamente los aspectos positivos.

La influencia europea se ha extendido a otros continentes. Los descendientes de los emigrantes europeos han forjado unos países que, por su semejanza en muchos aspectos, incluso en las condiciones naturales con el Viejo Continente han merecido el calificativo de «nuevas Europas». En casi todos ellos la población es predominantemente blanca. ${ }^{78}$

Desde otra perspectiva, la visión identitaria europeísta desprendería un deseo de pertenencia a Europa como comunidad. Si bien los manuales del tardofranquismo ya habían comenzado tímidamente a mostrar ese deseo de integración en Europa, como símbolo de pertenencia a una comunidad económica próspera, el discurso se acentúa en los setenta y ochenta. Sobre todo se evidencia el interés de que España fuera incluida en el sistema económico europeo y en el Mercado Común. Esa aspiración de pertenencia a Europa la observamos en un manual de Santillana de 1974, donde se presenta una columna de prensa internacional cuyo título es «La vocación europea de España». En el texto se muestra cómo se solicitaba la inclusión en la Comunidad Económica Europea, pues esto suponía también un reconocimiento para España. ${ }^{79}$ Es comprensible que la identificación con Europa fuera algo positivo, y sobre todo con su comunidad económica, ya que era considerada una comunidad exclusiva de países desarrollados con gran potencial. Veamos un ejemplo de la editorial Anaya de 1981:

\footnotetext{
inédito del proyecto: «Ciudadanía, identidades complejas y cultura política en los manuales escolares españoles (1978-2006)» (Madrid: UNED, 2008), 12.

${ }_{78}$ Domingo J. Sánchez Zurro, Isidoro González Gallego y Mariano Mañero Monedo. Ciencias Sociales $7^{\circ}$ (Salamanca: Anaya, 1975), 17.

${ }^{79}$ Abad, Consultor. Ciencias Sociales 8 $8^{\circ}, 471$.
} 
Proporcionalmente a su extensión, Europa es el continente más rico. Los diversos climas permiten una gran variedad de cultivos de los que sus habitantes obtienen grandes beneficios. Pero es en el comercio y en la industria donde Europa tiene su mayor fuerza económica. Las técnicas de fabricación europeas son muy apreciadas en el mundo y originan un comercio muy importante..$^{80}$

Al respecto, observamos también cómo la tercera parte del índice de un manual de Geografía e Historia de 1982 para $6^{\circ}$ curso de EGB, se titula "Fundamentos de la sociedad española y europea», 81 mostrando una dualidad pretendida a modo de inclusión y conexión, mediante una identificación positiva entre España y Europa.

En definitiva, observamos que la incorporación a Europa se mostraba en los manuales de los setenta y ochenta como culminación de un proyecto democrático y económico donde se recogían los deseos de bienestar social, desarrollo, renovación cultural, presencia internacional y referente de modernidad democrática. ${ }^{82}$ Observemos el siguiente ejemplo del año 1981:

España es Europa. Por circunstancias políticas nuestro país ha estado desgajado del proceso integrador que se inició con la creación del Mercado Común Europeo en 1957. Aunque en 1962 se solicitó por primera vez el ingreso en este organismo, en 1980 todavía no se había conseguido. Con la creación del Estado democrático, a partir de 1975, se ha abierto un camino que, no sin dificultades, nos conducirá a la integración en la llamada «Europa de los Diez», nombre dado al Mercado Común Europeo por el número de países que lo constituyen en $1980 .{ }^{83}$

En lo que respecta a la visión del nuevo paisaje como elemento configurador de identidades, los manuales escolares de los setenta siguen manteniendo el elemento desarrollista de origen regeneracionista de la

\footnotetext{
80 Joaquín Prats et al., Ciencias Sociales $7^{\circ}$ (Madrid: Anaya, 1981), 42.

81 Abad, Consultor. Ciencias Sociales $8^{\circ}, 471$.

82 Jorge Benedicto, «La construcción de la ciudadanía democrática en España (1977-2004): de la institucionalización a las prácticas», Revista Española de Investigaciones Sociológicas, REIS 114, no. 6 (2006): 109.

${ }_{83}$ Prats et al., Ciencias Sociales 8, 266.
} 
década anterior, que incidía en las posibilidades de los propios recursos naturales de España y su capacidad de producir riqueza por medio de los mismos. Continúa también la exaltación de determinadas obras de ingeniería civil, como pantanos, complejos industriales, carreteras y otras infraestructuras. ${ }^{84}$ Aparecen también los nuevos modelos urbanísticos como ciudades turísticas y ciudades dormitorio. Estas últimas eran las encargadas de recoger a la población del importante éxodo rural. Así era el paisaje que mostraban los manuales de los setenta, fortaleciendo el nuevo imaginario colectivo que había comenzado a estructurarse en la década anterior.

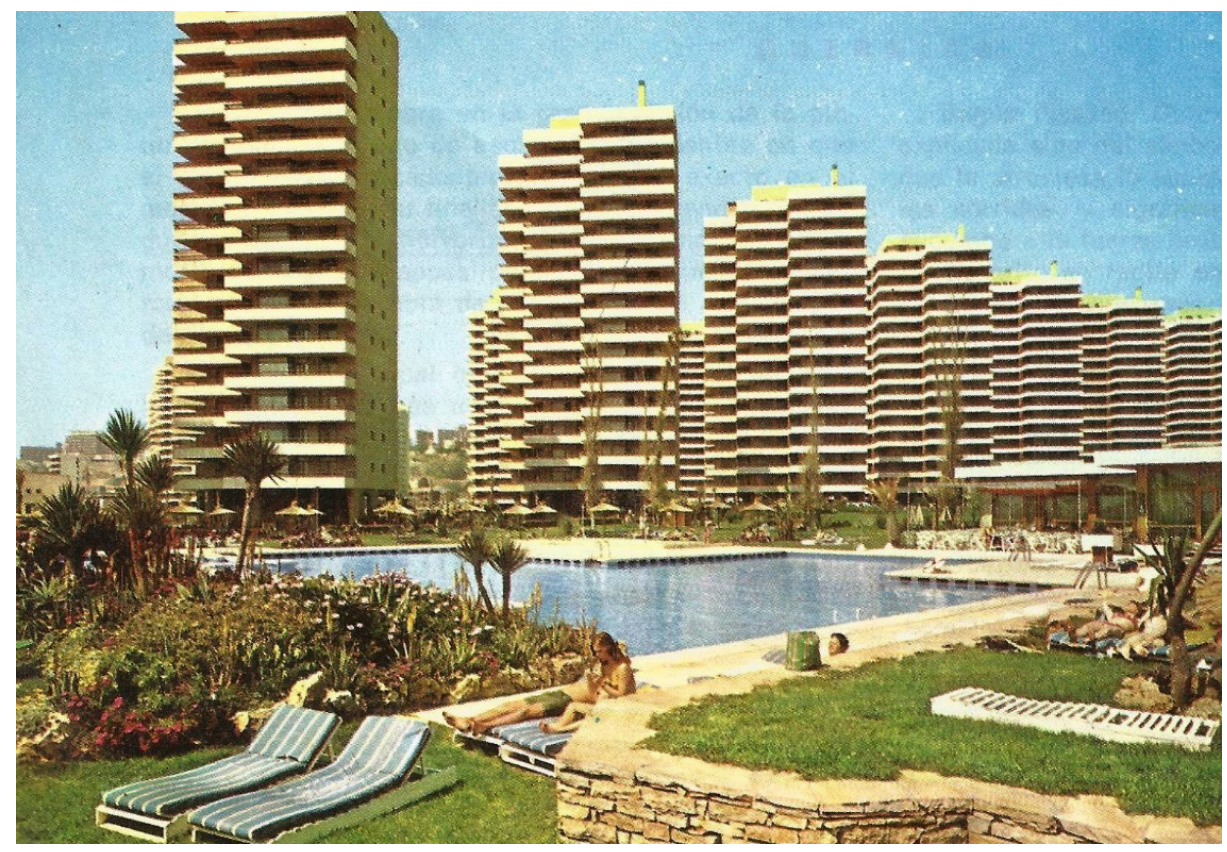

Imagen 5. Historia Universal y de España 8, 1978: "Complejo hotelero en Torremolinos (Málaga) ${ }^{85}$.

${ }^{84}$ Campos, Los relatos de la nación, 259.

${ }_{85}$ Rastrilla, Historia Universal y de España 8, 232. 


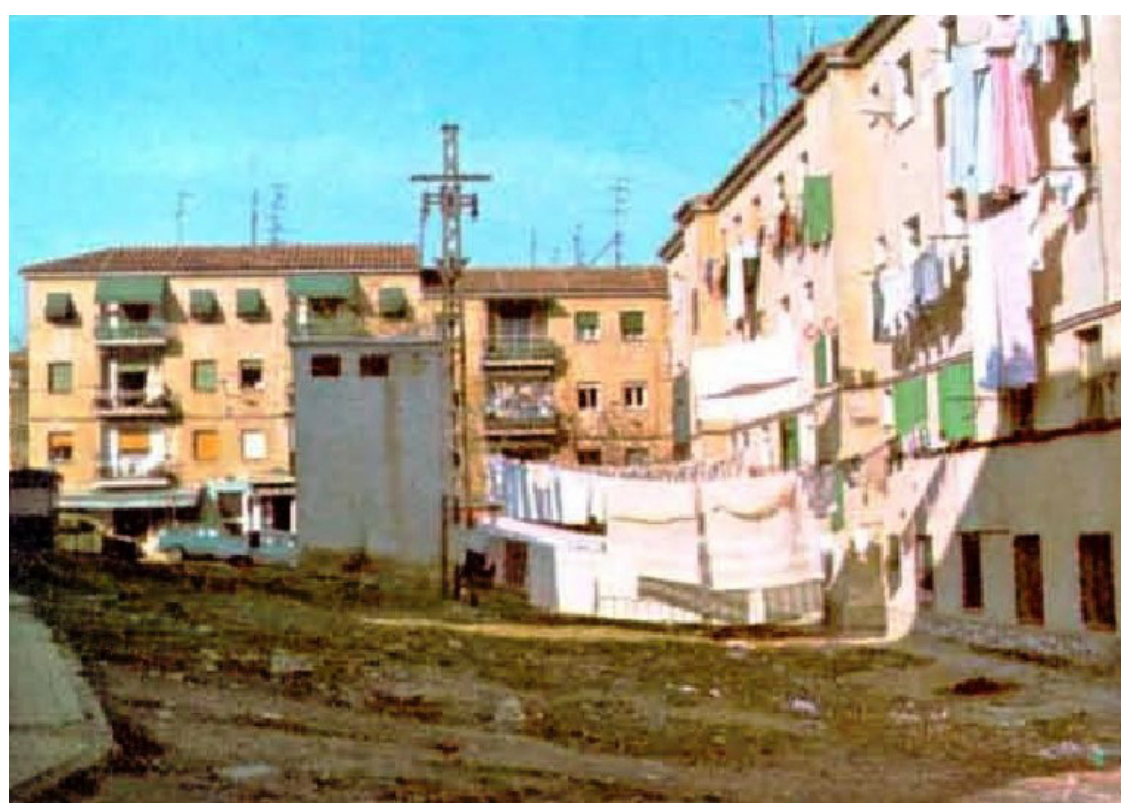

Imagen 6. Mundo y Sociedad 80, 1981: Nuevos barrios. ${ }^{86}$

El nuevo imaginario colectivo, que hacía confluir modernidad y raíces étnicas, sirvió también para vender al turismo la imagen de una España original y auténtica que fue reflejada a través del cine del «destape». Los toros, la canción folclórica o el fútbol también formaron parte de ese imaginario que exaltaba la geografía y el clima como cualidades definitorias nacionales y alababa los elementos folclóricos del país, dejando atrás el imaginario épico que el franquismo utilizó como seña de identidad. ${ }^{87}$ De hecho, no solo se exportó a turistas extranjeros, sino que también se suministró para el consumo nacional, fomentando a través de los contenidos curriculares la configuración de identidades afines a tales manifestaciones culturales. El país se había transformado en un lugar elegido por el turismo internacional, una especie de parque temático folclorista al que se le añadía un clima envidiable. Así lo describe un manual de 1977 de la editorial Miñón:

\footnotetext{
${ }^{86}$ Fernández, Mundo y Sociedad $8^{\circ}$ egb, 276.

${ }^{87}$ Lara Campos denomina a estas manifestaciones como «subcultura franquista». Campos, Los relatos de la nación, 260.
} 
[...] un clima favorable, con elevado número de horas de sol, una gran variedad regional con abundantes ejemplos de belleza natural y artística, y unos precios relativamente bajos en relación a los de los países industrializados de Europa o América del Norte. ${ }^{88}$

El paisaje turístico de sol y playa, asociado a importantes beneficios económicos y entrada de divisas, adquirió especial protagonismo en los manuales de los setenta y comienzos de los ochenta. Las imágenes de playas españolas abarrotadas de turistas y sombrillas, complejos hoteleros o el nuevo paisaje urbano del litoral español, se repiten incansablemente en los manuales, convirtiéndose en símbolos identitarios de la riqueza del país, de su desarrollo y del estado del bienestar. ${ }^{89}$ Sin embargo, este relato tampoco ofrecía información sobre las consecuencias negativas del turismo en masa, como la desaparición de los modos de vida tradicionales o el debate sobre la sostenibilidad de este modelo económico y paisajístico. De hecho, esa imagen de España era y es la que ha acabado grabada en la retina de muchos extranjeros y españoles.

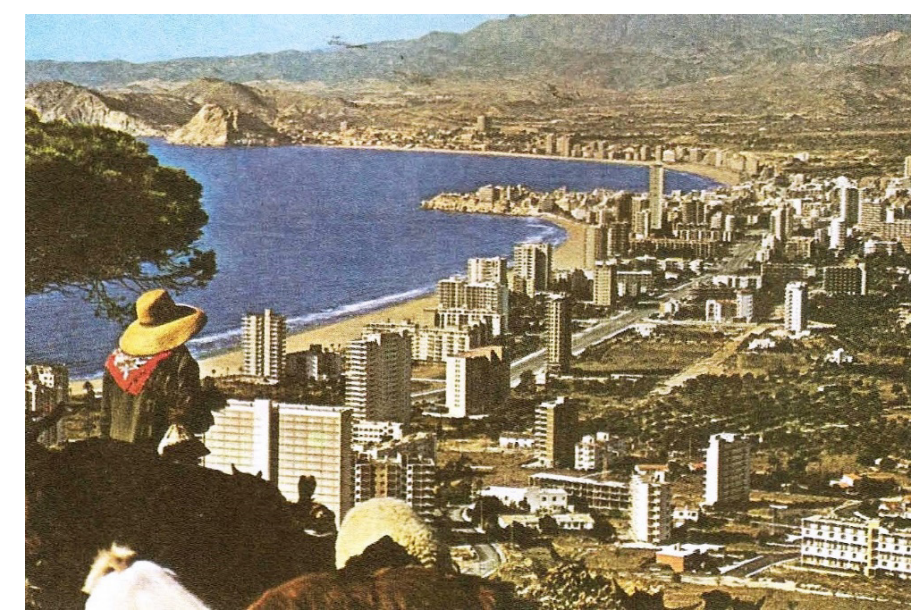

Imagen 7. Sociedad $8^{\circ}$. Nuestro Mundo, 1978. Benidorm ciudad turística. ${ }^{90}$

\footnotetext{
${ }^{88}$ Fernando Manero, Rosario Prieto y Emérita Ramos, Sociedad 6 EGB (Valladolid: Miñón, 1977), 218.

89 José López, Emérita Ramos y Antonio Álvarez, Sociedad 8. Nuestro Mundo (Valladolid: Miñón, 1978), 349; Prats et al., Ciencias Sociales 8, 94; Fernández, Llorens y Ortega, Historia Contemporánea, 276.

${ }_{90}$ López, Sociedad 8․ Nuestro Mundo, 349.
} 
También el nuevo proceso migratorio del campo a la ciudad, surgido del proceso desarrollista, y su repercusión en la creación de nuevos barrios de inmigrantes obreros, supuso un fenómeno que quedaría ligado a nuevas identidades colectivas, la identidad asociada a la ciudad. Según Cazorla, «la imagen y la identidad de barrio desarrollaron características particulares que se adscribían a sus habitantes y que, supuestamente, les diferenciaban de los otros vecindarios. Por eso, un barrio (o por la misma regla de tres, una ciudad) representaba tanto una señal de identidad como de exclusión». ${ }^{91}$

En definitiva, la imagen que formaría parte del paisaje simbólico que difundían los manuales era aquella que presentaba como deseable el nuevo estilo de vida urbano, aunque esta imagen simbólica fuera asociada a un discurso que criticaba, en ocasiones, su ritmo de vida frenético. Así lo describe un manual de Anaya del año 1981 en una sección que lleva como título «La vida en las ciudades»:

Mañana debe trabajar. Otra vez lo mismo: casa, coche, oficina, bar, amigos, etc. En la noche del domingo, muchos piensan, como Juan, en su ciudad. Que les ofrece muchas cosas: prisas, violencia, contaminación, trabajo, cultura, información, etcétera. Y, aunque a veces la odia, Juan se duerme enamorado de su ciudad. ${ }^{92}$

El imaginario de paisaje urbano se fue haciendo cada vez más presente en los manuales como símbolo de modernidad, en detrimento del paisaje rural, asociado a un escaso futuro, al retraso y al abandono. ${ }^{93}$ Este hecho es un indicador de la promoción de un nuevo ideal de ciudadano español desligado del mundo rural, facilitando así la configuración de una nueva identidad urbana.

\section{CONSIDERACIONES FINALES}

Desde la perspectiva de este trabajo podemos afirmar que las identidades pueden ser instrumentalizadas por los mecanismos de poder. Uno

\footnotetext{
91 Antonio Cazorla, Miedo y progreso. Los españoles de a pie bajo el franquismo, 1939-1975 (Madrid: Alianza, 2016), 183.

92 Prats et al., Ciencias Sociales 80, 166-167.

${ }_{93}$ Prats et al., Ciencias Sociales $8^{\circ}, 162$.
} 
de los instrumentos utilizados para configurar identidades acordes con las ideologías de los mecanismos de poder es el componente económico, presente en el currículum escolar y en el discurso de los manuales.

La identidad nacional española fue instrumentalizada por el franquismo, inicialmente con la imposición de los principios nacionalcatólicos y, posteriormente, a través de la exaltación propagandística de los logros económicos desarrollistas. Desde el discurso de los manuales se advierte cómo se modifican los procesos identitarios para adaptarlos al despegue económico, configurándose un nuevo nacionalismo de base economicista, que surge de la promoción constante de una autoimagen positiva del endogrupo a partir de buenas noticias económicas. Los logros económicos, profusamente difundidos, favorecen la cohesión de la nación durante la última fase del franquismo, convirtiéndose a su vez en una nueva legitimación política de la dictadura. Esta legitimación se ampara en un discurso económico que oculta las cuestiones negativas del desarrollo y muestra únicamente lo positivo, responsabilizando en exclusiva al régimen de los logros del despegue económico. El discurso económico promovido por los manuales de los sesenta no posibilita el fomento de una actitud crítica sobre las cuestiones negativas del modelo de desarrollo, y por tanto, la configuración de la identidad nacional bajo este discurso se convierte en una pretendida transmisión de adoctrinamiento nacionalista. ${ }^{94}$

Las representaciones simbólicas de las transformaciones físicas del territorio, derivadas del contexto económico, forman parte de un mecanismo capaz de configurar una identidad nacional mitificada, compatible ideológicamente con el régimen, a través de la promoción de un imaginario de la modernidad donde los patrones identitarios quedaban asociados al paisaje urbano y la metropolización del territorio. A la nueva concepción identitaria del territorio también contribuyó la promoción de una imagen de país turístico de sol y playa que los manuales representan como motor económico, con imágenes de gran carga simbólica que han condicionado la manera de vivir nuestra propia identidad en la actualidad.

${ }_{94}$ Atienza et al., «Identidad social», 87. 
El discurso de los manuales comienza a cambiar tras la muerte del dictador, dejando de ser tan propagandístico para comenzar a mostrar valoraciones negativas del proceso de desarrollo del país. Esto puede explicarse por la llegada de nuevas autorías y equipos editoriales que diversifican el discurso ideológico.

No obstante, el nuevo paisaje y el estilo de vida urbano que difunden los manuales se consolidan a finales de los setenta como factores configuradores de una nueva identidad urbana, asociada a un modelo económico que fomenta la vida en las ciudades en detrimento de la vida rural. El nuevo discurso también potencia el sentimiento de pertenencia a Europa como comunidad económica próspera y culminación del proyecto democrático, fomentando así identidades afines más amplias que la nacional, configuradas ahora en base al concepto de nación diversa y variada, pero indefectiblemente ligada a los mecanismos económicos de Occidente.

Los manuales de finales de los setenta y comienzos de los ochenta dan muestras de una introducción plena en el sistema capitalista occidental. El uso de cierta terminología técnica, económica y financiera se hace hueco en el discurso, ocultando los procesos de concentración de poder. No se cuestiona en ningún caso el modelo económico, ni se genera debate sobre la influencia de las grandes corporaciones ligadas al bloque occidental, o el control político que pueden ejercer sobre los gobiernos, legitimando así el modelo de dominación económica. De este modo, podemos afirmar que aunque el discurso económico ha ido evolucionando hacia posiciones más críticas, desde los manuales se sigue ofreciendo una visión del factor económico sesgada, incompleta, muy ideologizada, donde el sistema occidental y su economía de mercado constituyen la cumbre de la civilización sin cuestionamientos. Este hecho facilita la configuración de identidades económicas, sociales, políticas y culturales vinculadas a los patrones de la sociedad capitalista occidental.

\section{Nota sobre la autora}

Yovana Hernández Laina es doctora en «Diversidad, Subjetividad y Socialización. Estudios en Antropología Social, Historia de la Psicología y de la Educación» por la Universidad Nacional de Educación a Distancia 
(UNED). Realizó su tesis en condición de contratada predoctoral en el Departamento de Historia de la Educación y Educación Comparada de la UNED, con una beca FPI asociada al proyecto de investigación del Plan Nacional de I+D+i del Ministerio de Economía y Competitividad «La dimensión afectiva de la socialización política. Emociones y sentimientos en los manuales escolares de la Transición democrática española». Es también licenciada en Pedagogía por la Universidad de Burgos, maestra de educación primaria (UCM) y realizó el Máster interuniversitario Memoria y Crítica de la Educación (Universidad de Alcalá-UNED). Forma parte del Centro de investigación MANES (Manuales Escolares) de la UNED. Además, es miembro de la Sociedad Española de Historia de la Educación (SEDHE). Sus principales líneas de investigación se centran en el estudio de la cultura económica escolar, los manuales escolares, los procesos de socialización política, las identidades, emociones y sentimientos, el tardofranquismo y los procesos de transición política.

\section{ANEXO. MANUALES ANALIZADOS}

\section{Años sesenta}

Dalmáu, Carles. Enciclopedia Estudio. Libro azul. Ciclo Perfeccionamiento. Gerona/Madrid: Dalmáu, 1963.

Gonzalo Calavia, Leónides, dir. Ahora. La actualidad en lecturas formativas para escolares de 10 a 12 años. Madrid: Paraninfo, 1963.

Gosálbez Celdrán, Alfredo. Educación Cívico-Social 6º Madrid: Doncel, 1969. [2. ${ }^{a}$ edición].

Hernando, Vicente y Víctor Fernández Larrea. Lecturas históricas. Madrid: SM, 1964.

Legorburu, José. Geografía Elemental. Madrid: Ediciones SM, 1962.

Ojuel Gómez, Mariano. Geografía e Historia $6^{\circ}$. Barcelona: Prima Luce, 1967. Ortega, Rosa. Historia. Barcelona: Teide, 1965. [2ª edición].

Ramos, Emérita M., Antonio Álvarez y Cesáreo Herrero. Geografía e Historia. Séptimo curso. Valladolid: Miñón, 1968.

Ramos, Emérita M., Antonio Álvarez y Cesáreo Herrero. Geografía e Historia. Octavo curso. Valladolid: Miñón, 1968.

Serrano de Haro, Agustín. Mirando a España. Madrid: Paraninfo, 1963.

\section{Años setenta}

Abad, Julián, et al. Consultor. Ciencias Sociales $6^{\circ}$. Madrid: Santillana, 1972. 
Abad, Julián, et al. Consultor. Ciencias Sociales $7^{\circ}$. Madrid: Santillana, 1973. Abad, Julián, et al. Consultor. Ciencias Sociales 8. Madrid: Santillana, 1974. Coronas Tejada, Luis. Mundo y sociedad $8^{\circ}$. Madrid: Magisterio Español, 1974.

Fernández García, Antonio, Montserrat Llorens Serrano y Rosa Ortega Canadell. Historia Contemporánea. Orbe-País. $8^{\circ}$ curso de EGB. Barcelona: Vicens Vives, 1978. [4 ${ }^{a}$ edición].

Gómez, Carlos, et al. La Tierra y los hombres 8. Madrid: Magisterio Español, 1974.

López, José, Emérita Ramos y Antonio Álvarez. Sociedad 8․ Nuestro Mundo. Valladolid: Miñón, 1978.

Manero, Fernando, Rosario Prieto y Emérita Ramos. Sociedad 6 EGB. Valladolid: Miñón, 1977.

Rastrilla Pérez, Juan, et al. Historia Universal y de España 8. Madrid: SM, 1978.

Sánchez Zurro, Domingo J., Isidoro González Gallego y Mariano Mañero Monedo. Ciencias Sociales 7. Salamanca: Anaya, 1975.

\section{Años ochenta}

Albacete Sánchez, Juan, Javier Cuenca Escribano y José Ma Parra Ortiz. Sociedad 80. $8^{\circ}$ EGB. Madrid: Santillana, 1981.

Castejón, Pablo, et al. Sociedad 7. Madrid: Santillana, 1983.

Castejón, Pablo, José Luis Díez, Jaime Mascaró. Sociedad 8. Madrid: Santillana, 1984.

Fernández Sanz, Juan José y Gabriel García Voltá. Mundo y Sociedad $8^{\circ}$ egb. Madrid: SM, 1981.

Fernández Sanz, Juan José y Gabriel García Voltá. Mundo y Sociedad $7^{\circ}$ egb. Madrid: SM, 1983.

Fernández Sanz, Juan José y Gabriel García Voltá. Mundo y Sociedad $6^{\circ}$ egb. Madrid: SM, 1984.

Prats, Joaquín, et al. Ciencias Sociales 6. Madrid: Anaya, 1981.

Prats, Joaquín, et al. Ciencias Sociales $7^{\circ}$. Madrid: Anaya, 1981.

Prats, Joaquín, et al. Ciencias Sociales 8. Madrid: Anaya, 1981.

Rastrilla Pérez, Juan y Juan J. Arenaza Lasagabaster. Geografía e Historia $6^{\circ}$ egb. Madrid: Ediciones SM, 1982.

\section{REFERENCIAS}

Abad Asenjo, Andrés. «Cuestionarios y programas de Enseñanza Primaria». Revista de Educación 184 (1966): 54-58. 
Abella, Rafael. La vida cotidiana en España bajo el régimen de Franco. Barcelona: Argos Vergara, 1985.

Aguilar Fernández, Paloma. Memoria y olvido de la Guerra Civil española. Madrid: Alianza Editorial, 1996.

Apple, Michael. «El libro de texto y la política cultural». Revista de Educación 301 (1993): 109-126.

Atienza Cerezo, Encarna, y Teun A. Van Dijk. «Identidad social e ideología en libros de texto españoles de Ciencias Sociales». Revista de Educación 353 (2010): 67-106.

Badanelli, Ana María. «Representing two worlds: illustrations in Spanish textbooks for the teaching of religion and object lessons (1900-1970)». History of Education 41, no. 3 (2011): 303-338.

Badanelli, Ana María, y María del Mar del Pozo. «Desde la madre-patria española al estado de las autonomías: La idea de España en los manuales escolares (1900-2007)». Historia de la educación 27 (2008): 397-432.

Bajo Bajo, $\mathrm{M}^{\mathrm{a}}$. Jesús «El paisaje en el currículum de Educación Primaria, dentro del área del conocimiento del medio natural, social y cultural». Aula 13 (2001): 51-61.

Benedicto, Jorge. «La construcción de la ciudadanía democrática en España (1977-2004): de la institucionalización a las prácticas». Revista Española de Investigaciones Sociológicas, REIS 114, no. 6 (2006): 103-136.

Benedito Sifre, María Teresa, Armando Cervellera Martínez, y Xosé Manuel Souto González. "Los manuales escolares y la didáctica de la Geografía entre 1950 y 1990». En El libro escolar, reflejo de intenciones políticas e influencias pedagógicas, editado por Alejandro Tiana Ferrer, 63-86. Madrid: UNED, 2000.

Berger, Peter L., y Thomas Luckmann. La construcción social de la realidad. Buenos Aires: Amorrortu, 1988.

Bernecker, Walter L. «The change in mentalities during de late Franco Regimen». En Spain transformed. The late Franco Dictatorship, 1959-1975, editado por Nigel Townson, 67-84. Nueva York: Palgrave McMillan, 2007.

Billing, Michael. «El nacionalismo banal y la reproducción de la identidad nacional». Revista Mexicana de sociología 1 (1998): 37-57.

Bourdieu, Pierre. Las estrategias de la reproducción social. México: Siglo Veintiuno, 2011.

Boyd, Carolyn P. «De la memoria oficial a la memoria histórica: La Guerra Civil y la dictadura en los textos escolares de 1939 al presente». En Memoria de la guerra y del franquismo, editado por Santos Juliá, 79-99. Madrid: Taurus Ediciones, 2006.

Boyd, Carolyn P. Historia Patria. Política, historia e identidad nacional en España. 1875-1975. Barcelona: Ediciones Pomares Corredor, 2000. 
Bousquet, Jacques. Economía política de la educación. Madrid: Instituto de Estudios Políticos, 1960.

Cámara Villar, Gregorio. Nacional-catolicismo y Escuela. La Socialización Política del Franquismo, 1936-1951. Jaén: Hesperia, 1984.

Campos, Lara. Los relatos de la nación. Iconografía de la idea de España en los manuales escolares (1931-1983). Madrid: Centro de Estudios Políticos y Constitucionales, 2010.

Camprubí Bueno, Lino. Los ingenieros de Franco. Ciencia, catolicismo y Guerra Fría en el Estado franquista. Barcelona: Crítica, 2017.

Cañellas Mas, Antonio. «La tecnocracia franquista: el sentido ideológico del desarrollo económico». Studia Histórica. Historia contemporánea 24 (2006): 257-288.

Capel, Horacio. «Las ciencias sociales y el estudio del territorio». Revista bibliográfica de geografía y ciencias sociales, Biblio3w 21, no. 1.149 (2016). http:// www.ub.edu/geocrit/b3w-1149.pdf

Capel, Horacio. «La definición de lo urbano». Estudios Geográficos 138-139 (1975): 265-301.

Castells, Manuel. La era de la información. Economía, sociedad y cultura. Madrid: Alianza, 1998.

Castillejo, Emilio. «Análisis del contenido ideológico de los manuales de historia». Bordón. Revista de pedagogía 61, no. 2 (2009): 45-58.

Castillejo, Emilio. Mito, legitimación y violencia simbólica en los manuales escolares de Historia del franquismo (1936-1975). Madrid: UNED, 2008.

Castillejo, Emilio. «Indicaciones sobre la investigación. Ciudadanía, identidades complejas y cultura política en los manuales escolares españoles (19782006)». Documento de trabajo inédito del proyecto: "Ciudadanía, identidades complejas y cultura política en los manuales escolares españoles (1978-2006)». Madrid: UNED, 2008.

Cazorla, Antonio. Miedo y progreso. Los españoles de a pie bajo el franquismo, 1939-1975. Madrid: Alianza, 2016.

De Miguel, Jesús M. «¿Desarrollo o desigualdad? Análisis de una polémica sociológica de medio siglo en España». Revista española de investigaciones sociológicas, REIS 75 (1996): 55-108.

Fairclough, Norman. Critical discourse analysis. London: Longman, 1995.

Fairclough, Norman. «El Análisis Crítico del Discurso como método para la investigación en Ciencias Sociales». En Métodos de análisis crítico del discurso, editado por Ruth Wodak, y Michael Meyer, 143-178. Barcelona: Gedisa, 2003.

Fairclough, Norman. Language and Power. London: Longman, 1989.

Fusi, Juan Pablo. «La cultura». En Franquismo. El juicio de la historia, editado por José Luis García Delgado, 219-295. Madrid: Temas de hoy, 2000. 
Foucault, Michel. Hay que defender la sociedad. Buenos Aires: Almagesto, 1992.

García Delgado, José Luis. «La economía». En Franquismo. El juicio de la historia, editado por José Luis García Delgado, 147-217. Madrid: Temas de hoy, 2000.

Geertz, Clifford. «Ideology as a Cultural System». En Ideology and Discontent, editado por David Apter, 47-56. NY: The Free Press of Glencoe, 1964.

Giddens, Anthony. Modernidad e identidad del yo. Barcelona: Península, 1995.

Hernández Laina, Yovana. «Cultura económica y socialización política en los manuales escolares del tardofranquismo y la Transición española (19601985)». PhD diss., Universidad Nacional de Educación a Distancia (UNED), 2018.

Justel, Manuel. "Edad y cultura política». Revista española de investigaciones sociológicas, REIS 58 (1992): 57-96.

Linz, Juan. «Legitimacy of Democracy and the Socioeconomic System». En Comparing Pluralist Democracies. Strains on Legitimacy, editado por Mattei Dogan, 65-113. London: Westview Press, 1988.

Longenecker, Bruce, y Kelly Liebengood. Engaging Economics: New Testament Scenarios and Early Christian Reception. Michigan and Cambridge: William Eerdmans Publishing Company, 2009.

López Facal, Ramón. «El nacionalismo español en los manuales de Historia». Educació i Història. Revista d'Història de l'educació 2 (1995): 119-128.

Mayordomo, Alejandro. «Regenerar la sociedad, Construir el Patriotismo o la Ciudadanía: Educación y Socialización Política en la España del siglo XX». Encounters in Theory and History of Education 1 (2008): 49-80.

Méndez, Leticia. Identidad: análisis y teoría, simbolismo, sociedades complejas, nacionalismo y etnicidad. México: UNAM, 1996.

Milito Barone, Cecilia C. «Conflicto y convivencia en el discurso pedagógico oficial durante el tardofranquismo y la Transición democrática española (1965-1982)». PhD diss., Universidad Nacional de Educación a Distancia (UNED), 2019.

Morón Monge, María del Carmen, Hortensia Morón Monge, y Jesús Estepa Giménez. «El paisaje en el currículum oficial y los libros de texto de Ciencias Sociales de la ESO: una perspectiva patrimonial integral». En Actas I Congreso Internacional de Educación Patrimonial: Mirando a Europa: estado de la cuestión y perspectivas de futuro, 564-573. Madrid: IPCE, 2012.

Nates Cruz, Beatriz. «Soportes teóricos y etnográficos sobre conceptos de territorio». Revista Co-herencia 8, no. 14 (2011): 209-229.

Nogué, Joan. «Nacionalismo, territorio y paisaje en Cataluña». En Paisaje, memoria histórica e identidad nacional, editado por Nicolás Ortega Cantero, 
147-169. Madrid: Universidad Autónoma de Madrid y Fundación Duques de Soria, 2005.

Nogué, Joan. «Territorios sin discurso, paisajes sin imaginario. Retos y dilemas». Ería 73-74 (2007): 372-382.

Oteiza, T. «How contemporary history is presented in Chilean middle school textbooks». Discourse and Society 14 (2002): 639-662.

Pérez Garzón, Juan Sisinio. «¿Por qué enseñamos Geografía e Historia? ¿Es tarea educativa la construcción de identidades?». Revista Historia de la Educación 27 (2009): 37-55.

Pérez Urraza, Karmele, Gurutze Ezkudia Arteaga, y Begoña Bilbao Bilbao. «El paisaje: un concepto básico en el currículum desarrollado en los libros de texto del País Vasco». Espacio, Tiempo y Educación 2, no. 2 (2015): 225-242.

Pozo Andrés, María del Mar del. «Imágenes e historia de la educación: construcción, reconstrucción y representación de las practicas escolares en el aula». Historia de la Educación. Revista interuniversitaria 25 (2006): 291315.

Pujadas Muñoz, Joan-Josep. Etnicidad. Identidad cultural de los pueblos. Madrid: Eudema, 1993.

Rodríguez Lestegás, Francisco. «Territorialidad y pertenencia: la construcción geográfica de identidades». En Identidad y ciudadanía: reflexiones sobre la construcción de identidades, coordinado por Francisco Rodríguez Lestegás, 141-165. Barcelona: Horsori, 2008.

Sánchez Jiménez, José. «La España de los 'sesenta'. La recepción y las influencias de la 'Pacem in Terris' en una sociedad en vías de desarrollo». Sociedad y Utopía. Revista de Ciencias Sociales 42 (2013): 108-136.

Sanchidrián Blanco, María del Carmen. «El uso de imágenes en la investigación histórico-educativa». Revista de investigación educativa, RIE 29, no. 2 (2011): 295-310.

Saz Campos, Ismael. "Fascism, Fascistization and Developmentalism in Franco's Dictatorship». Social History 29, no. 3 (2004): 352-353.

Sepúlveda, Isidro. "La eclosión nacionalista: regionalismos, nacionalismos y autonomías». En Historia de la Transición (1975-1986), editado por Javier Tusell y Álvaro Soto, 409-443. Madrid: Alianza, 1996.

Valls, Rafael. «Fuentes y referentes del saber escolar: los actuales manuales escolares (de historia) y criterios para su análisis y valoración». En Las competencias profesionales para la enseñanza-aprendizaje de las ciencias sociales ante el reto europeo y la globalización, editado por Rosa María Ávila, José R. López y Estibaliz Fernández, 499-512. Bilbao: Asociación Universitaria de Profesores de Didáctica de las Ciencias Sociales, 2007. 
Van Dijk, Teun A. «El análisis crítico del discurso». Anthropos 186 (1999): 2336.

Van Dijk, Teun A. «Ideología y análisis del discurso». Estudio 29 (2005): 9-36. Weber, Max. Economía y Sociedad. México: Fondo de Cultura Económica, 1979.

Weber, Max. El político y el científico. Madrid: Alianza, 1987. 